\title{
Adhesive and Signaling Functions of Cadherins and Catenins in Vertebrate Development
}

\author{
Ewa Stepniak ${ }^{1}$, Glenn L. Radice², and Valeri Vasioukhin ${ }^{1,3}$ \\ ${ }^{1}$ Division of Human Biology, Fred Hutchinson Cancer Research Center, Seattle, Washington, 98109 \\ ${ }^{2}$ Center for Translational Medicine, Department of Medicine, Jefferson Medical College, Philadelphia, \\ Pennsylvania 19107 \\ ${ }^{3}$ Department of Pathology and Institute for Stem Cell and Regenerative Medicine, University of Washington, \\ Seattle, Washington 98195 \\ Correspondence: vvasiouk@fhcrc.org
}

Properly regulated intercellular adhesion is critical for normal development of all metazoan organisms. Adherens junctions play an especially prominent role in development because they link the adhesive function of cadherin-catenin protein complexes to the dynamic forces of the actin cytoskeleton, which helps to orchestrate a spatially confined and very dynamic assembly of intercellular connections. Intriguingly, in addition to maintaining intercellular adhesion, cadherin-catenin proteins are linked to several major developmental signaling pathways crucial for normal morphogenesis. In this article we will highlight the key genetic studies that uncovered the role of cadherin-catenin proteins in vertebrate development and discuss the potential role of these proteins as molecular biosensors of external cellular microenvironment that may spatially confine signaling molecules and polarity cues to orchestrate cellular behavior throughout the complex process of normal morphogenesis.

D evelopment of any multicellular organism is impossible without a dynamic and properly regulated intercellular adhesion. Adhesive contacts between cells provide a physical anchoring system that is necessary to form highly organized tissues, and these contacts are essential for effective intercellular communication that ensures the homeostasis and survival of the entire organism. A number of unique developmental processes, including such early events as embryonic compaction and first cell fate specification, as well as later tissue morphogenesis and organogenesis, rely on a dynamic balance between cellular adhesion and migration. Cadherin-catenin protein complexes, which constitute the core of a specialized subtype of cellular adhesion structures termed adherens junctions (AJs), play a particularly important role during these processes. Apart from maintaining adhesive contacts at the cell-cell junctions, they are actively involved in epithelial-to-mesenchymal and mesenchymal-to-epithelial transitions, which are crucial to sustain the tissue plasticity

Editors: W. James Nelson and Elaine Fuchs

Additional Perspectives on Cell Junctions available at www.cshperspectives.org

Copyright (C) 2009 Cold Spring Harbor Laboratory Press; all rights reserved; doi: 10.1101/cshperspect.a002949

Cite this article as Cold Spring Harb Perspect Biol 2009;1:a002949 
during development. Most importantly, the components of cadherin-catenin complexes are tightly linked to several major signaling networks controlling cell division, differentiation, and apoptosis and this feature is crucial for the broad roles of the AJs throughout the vertebrate development (see Cavey and Lecuit 2009).

This article will focus on the role of cadherin-catenin proteins in regulating the signaling events critical for vertebrate development. Altering the expression pattern of particular cadherin-catenin complex components in the developing embryo often leads to major developmental defects, which reflect their role in both signaling and mechanical adhesion. In this article, we will highlight crucial findings suggesting that cadherincatenin complexes provide not only the structural integrity of the tissue, but may also serve as biosensors of the external cellular microenvironment that modulate cellular behavior and make individual cells work together to ensure the fitness of the entire organism.

\section{STRUCTURAL AND FUNCTIONAL FEATURES OF CADHERIN-CATENIN COMPLEXES}

Core Components and their Functional

Connection to the Actin Cytoskeleton

AJs are a specialized type of cellular adhesion structures formed by complex and highly dynamic interactions between two families of proteins: cadherins and catenins. The main building blocks of AJs involve classical cadherins, with $\mathrm{E}$ (epithelial)-cadherin being a prototypic member of this family, and several closely related members of the armadillo repeat protein superfamily: p120-, $\beta$ - and $\gamma$-catenin (plakoglobin), as well as structurally unrelated and lacking armadillo domains $\alpha$-catenin (Niessen 2007; Hartsock and Nelson 2008) (see also Meng and Takeichi 2009). Other well-known members of the classical cadherin family include $\mathrm{N}($ neural $)-, \mathrm{P}($ placental)-, VE-(vascular-endothelial), R(retinal)-, and $\mathrm{K}$ (kidney)-cadherins (Hulpiau and van Roy
2009). Similarly, depending on the tissue type, three $\alpha$-catenin genes may be involved in formation of AJs: $\alpha \mathrm{E}$ (epithelial)-, $\alpha \mathrm{N}$ (neural)-, and $\alpha \mathrm{T}$ (testis)-catenins (Nagafuchi et al. 1991; Hirano et al. 1992; Claverie et al. 1993; Janssens et al. 2001). The assembly of AJs is triggered by homophilic binding of the extracellular parts of cadherin molecules on the neighboring cells and a binding of their cytoplasmic tails to p120-catenin and either of two closely related proteins, $\beta$-catenin or plakoglobin (Fig. 1). While p120-catenin acts to stabilize cadherins at the cell surface (Reynolds and Carnahan 2004), $\beta$-catenin provides a link to $\alpha$-catenin (Aberle et al. 1994), which in turn has the ability to provide a functional link to the actin cytoskeleton, thus promoting AJ protein clustering and stabilization of cellular adhesion (Hirano et al. 1992). Because binding of $\alpha$-catenin to actin filaments and $\beta$-catenin is mutually exclusive, it is unlikely that it can directly bridge AJs with the actin cytoskeleton (Drees et al. 2005; Yamada et al. 2005). Instead, it can link them indirectly, through interaction with another actinbinding protein, eplin (Abe and Takeichi 2008). Moreover, through interaction with formins, $\alpha$-catenin can regulate junctional actin polymerization (Vasioukhin et al. 2000; Kobielak et al. 2004). Besides $\alpha$-catenin, p120-catenin has also a pivotal role in the actin cytoskeleton dynamics at the AJs by regulation of Rho-family small GTPases (Reynolds 2007). The ability of AJs' core components to reorganize the actin cytoskeleton makes the assembly of cadherin-catenin adhesion complexes a highly dynamic process, which allows spatial reorganization of cells during normal development.

\section{A Crosstalk between the Cadherin-Catenin Complexes and Major Developmental Signaling Pathways}

Besides their structural role in stabilizing adhesive contacts between the neighboring cells and directing actin cytoskeleton reorganization, components of the cadherin-catenin complex are tightly linked to several key signal 


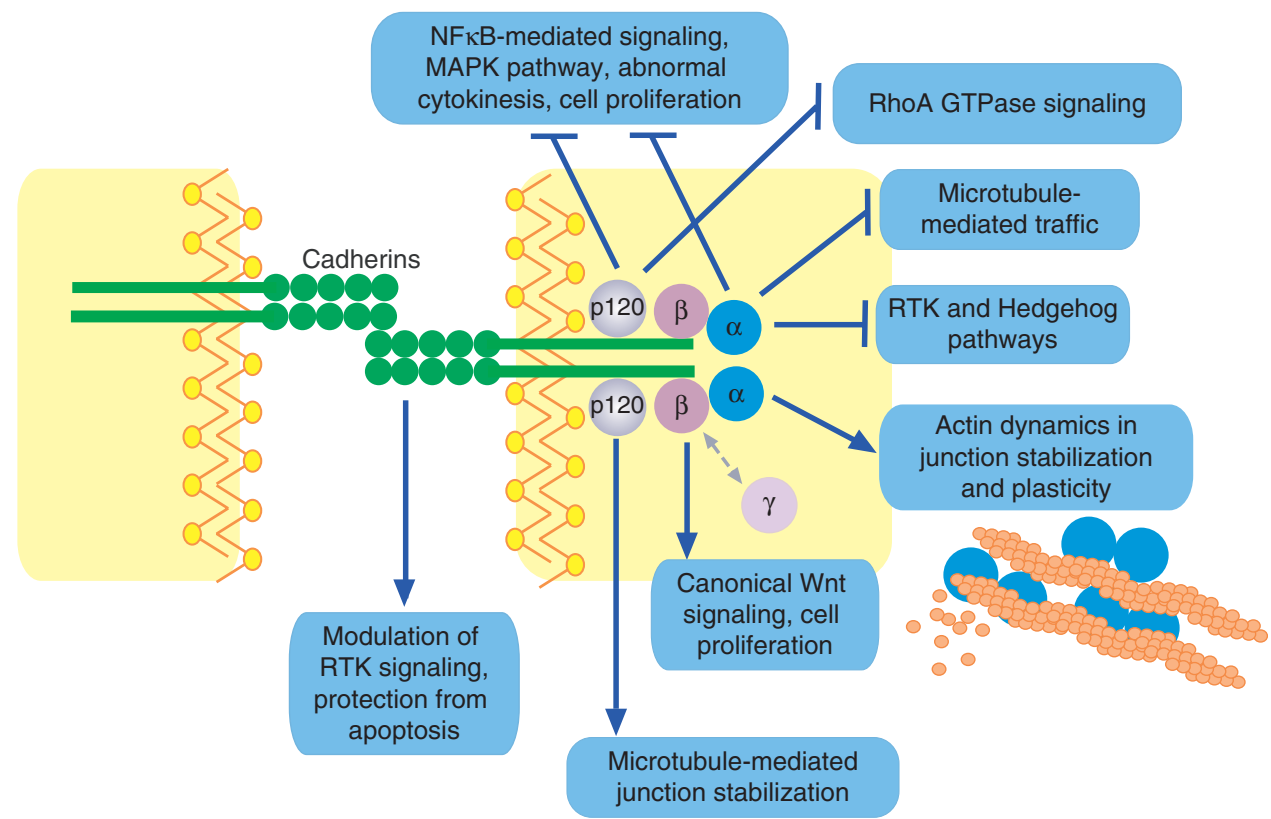

Figure 1. Cadherin-catenin proteins and their connections to developmental cell signaling pathways. Diagram showing major proteins involved in formation of cadherin, $\alpha-, \beta-, \gamma-$, and p120-catenin complexes at the plasma membranes of two juxtaposed cells. Although cadherins are implicated in regulation of receptor-type tyrosine kinases (RTKs) and protection from apoptosis, catenins have multiple overlapping and distinct functions. Both p120-catenin and $\alpha$-catenin regulate NFKB and MAPK signaling pathways, cytokinesis, and cell proliferation. However, p120-catenin has a unique function in the control of RhoA signaling and microtubule cytoskeleton organization, whereas $\alpha$-catenin is implicated in regulation of RTKs, Hedgehog signaling, microtubulemediated traffic, and functional coupling between the junctions and the actin cytoskeleton. $\beta$-catenin is a principal player in the canonical Wnt signaling pathway. Because RTKs, Hedgehog, and Wnt signaling mechanisms are heavily implicated in regulation of normal development, intriguing connections between cadherin-catenin receptors and these pathways provides potential tools for integrating the efforts of individual cells into a smoothly orchestrated developmental process.

transduction networks (Fig. 1). For example, $\beta$-catenin is a central player in the canonical Wnt signaling pathway, where it translocates to the nucleus and functions as a transcriptional cofactor (Clevers 2006; Grigoryan et al. 2008). One potential determinant of $\beta$-catenin's availability to participate in either the adhesion or transcriptional complexes may lay in its phosphorylation status. Indeed, $\beta$-catenin can be phosphorylated by a variety of serine/threonine and tyrosine kinases and this can profoundly change the ability of $\beta$-catenin to interact with cadherin and $\alpha$-catenin, as well as its signaling function (Piedra et al. 2003; Brembeck et al. 2004; van Buul et al. 2005; Brembeck et al. 2006; Coluccia et al. 2006; Zinser et al. 2006; Coluccia et al. 2007;
Daugherty and Gottardi 2007; Kajiguchi et al. 2007; Rhee et al. 2007). Overall, it appears that phosphorylation-mediated destabilization of cadherin-catenin complexes often results in activation of $\beta$-catenin signaling.

In addition to $\beta$-catenin, other members of the cadherin-catenin adhesion complex also play important roles in regulation of developmental cellular signaling networks. For example, receptor-type tyrosine kinase (RTK) pathways play a critical role in metazoan development. Cadherin-catenin complexes bind to and regulate the activity of a variety of RTKs (Erez et al. 2005). Interestingly, this interaction is often functionally complex. Although at steady state levels E-cadherin inhibits RTK signaling (Qian et al. 2004), formation of AJs 
can induce transient activation of RTKs (Pece and Gutkind 2000). Moreover, the outcome of functional interaction also depends on the type of involved cadherin and RTK molecules. For example, N-cadherin is generally a positive regulator of FGF receptor signaling (Suyama et al. 2002).

Both, p120- and $\alpha$-catenins have been recently implicated in the control of NFKB (nuclear factor $\kappa \mathrm{B}$ ) signaling pathway, which is involved in cell stress and survival and often hyperactivated in cancer (Kobielak and Fuchs 2006; Perez-Moreno et al. 2006). Although exact mechanisms responsible for the connection between catenins and NFKB signaling are not well understood, p120-catenin's role in this context has been linked to the control of RhoA-dependent signaling (Perez-Moreno et al. 2006; Perez-Moreno et al. 2008). Likewise, studies on the role of $\alpha$-catenin in epidermal development revealed an interesting link between this protein and Ras-MAPK pathway (Vasioukhin et al. 2001). Further studies using mice lacking $\alpha$-catenin in developing neural progenitors uncovered the role of this protein in the negative regulation of the Hedgehog signaling pathway, one of the major developmental pathways in vertebrates (Lien et al. 2006b).

Overall, a significant amount of information has been accumulated, which indicates that cadherin-catenin complexes are not only responsible for mechanical intercellular adhesion, but they also provide a dynamic link to major developmental signaling networks. These features may explain why cadherin-catenin proteins are among the key regulators of principal vertebrate developmental events, which will be discussed in detail in the following section.

\section{CADHERINS AND CATENINS IN VERTEBRATE DEVELOPMENT}

Loss-of-function experiments have been very informative in uncovering the role and significance of specific members of cadherincatenin complexes in vertebrate development. This is usually accomplished by the analyses of the mutant embryos, which are generated by targeted gene mutations, transgenic expression of dominant-negative constructs or injection of morpholino antisense oligos, interfering with translation of specific mRNAs. These experiments revealed that many core components of the AJs are essential for embryonic development (Table 1). Thus, conditional and tissue-specific gene knockout experiments were used to analyze the function of essential cadherin-catenin proteins at the later developmental time points. Altogether, these experiments revealed a highly complex picture concerning the function of these proteins in the developing embryo (Fig. 2).

\section{Early Embryogenesis}

During early embryonic development, significant amounts of E-cadherin and $\alpha \mathrm{E}$-catenin are provided maternally and mediate blastomere adhesion during embryonic compaction (Ohsugi et al. 1996; De Vries et al. 2004). Later, E-cadherin produced by the embryo becomes necessary for normal development, as zygotic E-cadherin-null embryos fail to form a trophectodermal epithelium and are unable to generate blastocyst cavity (Larue et al. 1994; Ohsugi et al. 1997). A unique role of E-cadherin in trophectoderm development was recently shown by gene replacement experiments (Kan et al. 2007). In this approach, $\mathrm{N}$-cadherin expressed from the E-cadherin locus was unable to rescue the lethality of E-cadherin-null embryos, as it was insufficient to drive the formation of functional trophectoderm (Kan et al. 2007). Remarkably, ES cells generated from these mutants were able to form an epithelium, indicating that despite the fact that N-cadherin is capable of supporting epithelial morphogenesis, E-cadherin has a very unique function in trophectoderm formation. Interestingly, the phenotype of zygotic $\alpha$ E-catenin-null embryos has striking similarities to embryos missing E-cadherin. The gene-trap mutants missing the actin-binding domain of $\alpha \mathrm{E}$-catenin show disruption of trophoblast epithelium and the development is consequently blocked at the blastocyst stage (Torres et al. 1997). This striking similarity 


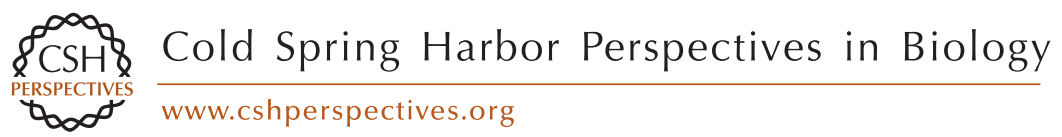

Table 1. Phenotypes of zygotic and conditional mutations of cadherin-catenin genes in mice

\begin{tabular}{|c|c|c|c|c|}
\hline Gene & Tissue/Time & $\mathrm{Cre}^{\mathrm{a}}$ & Phenotype & Ref. \\
\hline \multirow[t]{8}{*}{ E-cadherin (CDH1) } & $\begin{array}{l}\text { Maternal contribution to } \\
\text { oocyte }\end{array}$ & ZP3-Cre & Normal development via zygotic expression & (De Vries et al. 2004) \\
\hline & Zygote & & Lethal at E4; defects in trophectoderm & $\begin{array}{l}\text { (Larue et al. 1994; } \\
\quad \text { Riethmacher et al. 1995) }\end{array}$ \\
\hline & $\begin{array}{l}\text { Zygote (gene replacement, } \\
\text { N-cadherin into } \\
\text { E-cadherin locus) }\end{array}$ & & $\begin{array}{l}\text { Lethal; insufficient to rescue trophectoderm } \\
\text { defects }\end{array}$ & (Kan et al. 2007) \\
\hline & Epidermis/E11.5 & K14-Cre & Hair follicle degeneration, progressive hyperplasia & (Tinkle et al. 2004) \\
\hline & Epidermis/E11.5 & K14-Cre & Lethal at P0; failure of tight junctions formation & (Tunggal et al. 2005) \\
\hline & Epidermis/P15 & Krox20-Cre & Loss of hair follicles; abnormal differentiation & (Young et al. 2003) \\
\hline & Liver/E15 & Alfp-Cre & No phenotype & (Battle et al. 2006) \\
\hline & Mammary gland & MMTV-Cre & $\begin{array}{l}\text { Impaired differentiation and apoptosis of alveolar } \\
\text { epithelial cells }\end{array}$ & (Boussadia et al. 2002) \\
\hline \multirow[t]{7}{*}{$\mathrm{N}$-cadherin (CDH2) } & Zygote & & Lethal at E10; loss of cardiomyocyte adhesion & (Radice et al. 1997b) \\
\hline & Zygote + transgene rescue & & $\begin{array}{l}\text { Lethal at E12; rescue of heart defects by both } \\
\mathrm{N} \text {-cadherin or E-cadherin expression }\end{array}$ & (Luo et al. 2001) \\
\hline & $\begin{array}{l}\text { Chimeric embryos/N-cad } \\
\text { null ES cells }\end{array}$ & & $\begin{array}{l}\text { Exclusion and segregation of mutant cells from } \\
\text { wild-type cells }\end{array}$ & (Kostetskii et al. 2001) \\
\hline & Endothelial cells/E9.5-E11.5 & Tie2-Cre & $\begin{array}{l}\text { Lethal at mid-gestation; vascular morphogenesis } \\
\text { defects }\end{array}$ & (Luo and Radice 2005) \\
\hline & Cerebral cortex/E10.5 & D6-Cre & Complete disorganization of cerebral cortex & (Kadowaki et al. 2007) \\
\hline & Neural Crest & Wnt1-Cre & $\begin{array}{l}\text { Lethal; aberrant remodeling of cardiac outflow } \\
\text { tract }\end{array}$ & (Luo et al. 2006) \\
\hline & Epicardium & Wnt1-Cre & $\begin{array}{l}\text { Lethal; disruption of epicardial-myocardial cell } \\
\text { interactions thinning of the myocardial wall }\end{array}$ & (Luo et al. 2006) \\
\hline P-cadherin (CDH3) & Zygote & & Precocious differentiation of the mammary gland & (Radice et al. 1997a) \\
\hline R-cadherin (CDH4) & Zygote & & Live and fertile; dilated kidney proximal tubules & (Dahl et al. 2002) \\
\hline VE-cadherin (CDH5) & Zygote & & Lethal at E9.5; severe vascular defects & $\begin{array}{l}\text { (Carmeliet et al. 1999; } \\
\text { Gory-Faure et al. 1999) }\end{array}$ \\
\hline K-cadherin (CDH6) & Zygote & & $\begin{array}{l}\text { Live and fertile; delayed mesenchymal to epithelial } \\
\text { conversion during kidney development }\end{array}$ & (Mah et al. 2000) \\
\hline
\end{tabular}




\begin{tabular}{|c|c|c|c|c|}
\hline Gene & Tissue/Time & $\mathrm{Cre}^{\mathrm{a}}$ & Phenotype & Ref. \\
\hline Cadherin-8 (CDH8) & Zygote & & $\begin{array}{l}\text { Live and fertile; defective coupling between } \\
\text { cold-sensitive sensory neurons and their target } \\
\text { spinal cord neurons }\end{array}$ & (Suzuki et al. 2007) \\
\hline OB-cadherin (CDH11) & Zygote & & $\begin{array}{l}\text { Live and fertile; increased long term neuronal } \\
\text { potentiation, reduced fear- and anxiety-related } \\
\text { responses, reduced bone density, hypoplastic } \\
\text { synovial lining and resistance to arthritis }\end{array}$ & $\begin{array}{l}\text { (Horikawa et al. 1999; } \\
\text { Manabe et al. 2000; } \\
\text { Kawaguchi et al. 2001; Lee } \\
\text { et al. 2007) }\end{array}$ \\
\hline M-cadherin (CDH15) & Zygote & & Live and fertile; no developmental defects & (Hollnagel et al. 2002) \\
\hline BILL-cadherin (CDH17) & Zygote & & Abnormal immune B cell development & (Ohnishi et al. 2005) \\
\hline Otocadherin (CDH23) & Zygote & & $\begin{array}{l}\text { Deafness and vestibular defects because of } \\
\text { degeneration of the organ of Corti and other } \\
\text { inner ear structures }\end{array}$ & $\begin{array}{l}\text { (Wilson et al. 2001; } \\
\text { Noben-Trauth et al. 2003) }\end{array}$ \\
\hline E-cadherin $+P$-cadherin & Epidermis/E11.5 & K14-Cre & Lethal; severe epidermal adhesion defects, & (Tinkle et al. 2008) \\
\hline
\end{tabular}

\begin{tabular}{|c|c|c|}
\hline \multirow[t]{5}{*}{$\alpha$ E-catenin } & Zygote & \\
\hline & Epidermis/E11.5 & K14-Cre \\
\hline & CNS/E10.5 & Nestin-Cre \\
\hline & Mammary epithelium/adult & MMTV-Cre \\
\hline & Myocardium/E9 & MLC2v-Cre \\
\hline$\alpha N$-catenin & Zygote & \\
\hline \multirow[t]{6}{*}{$\beta$-catenin } & Zygote & \\
\hline & $\begin{array}{l}\text { Primitive streak; presomitic } \\
\text { mesoderm/E7.5 }\end{array}$ & $\begin{array}{l}\text { T-Cre } \\
\text { (Brachyury-C }\end{array}$ \\
\hline & CNS/E8.5 & Nes8-Cre \\
\hline & $\begin{array}{l}\mathrm{CNS} \text {, neural crest } \\
\text { progenitors/E9 }\end{array}$ & Wnt1-Cre \\
\hline & & Wnt1-Cre \\
\hline & CNS/E9.5 & FoxG1-Cre \\
\hline
\end{tabular}
apoptosis

Lethal at E4; defects in trophectoderm

(Torres et al. 1997)

Lethal at P0; loss of adhesion, hyperproliferation (Vasioukhin et al. 2001)

Lethal at P14-21; brain dysplasia, (Lien et al. 2006b) hyperproliferation

Abnormal differentiation, increased apoptosis

Defects in intercalated discs, cardiomyopathy

Cerebellar and hippocampal lamination defects, axonal migration abnormalities

Lethal at E8; failure of primitive streak formation

Mesoderm formation defects and abnormal segmentation

Dorsal-ventral fate shift before neurogenesis

Loss of cerebellum, failure of craniofacial development, cardiac outflow tract defects

Impaired migration of neural crest cells, loss of melanocytes and dorsal root ganglia

Lack of the entire forebrain and anterior facial

(Nemade et al. 2004)

(Sheikh et al. 2006)

(Park et al. 2002a; Uemura and Takeichi 2006

(Haegel et al. 1995)

(Aulehla et al. 2008; Dunty et al. 2008)

(Backman et al. 2005)

(Brault et al. 2001) (Kioussi et al. 2002

(Hari et al. 2002) structure

(Junghans et al. 2005) 
CNS/E10

Brn4-Cre

Apical ectodermal ridge/E10 Brn4-Cre CNS/E10.5 D6-Cre

Embryonic endoderm/E6.25 K19-Cre Head and limb mesenchyme/ Prx1-Cre E9 E10.5

Limb ectoderm/E9.5 Msx2-Cre

Epidermis/E11.5 K14-Cre

Vascular endothelium/ E8.5 Tie2-Cre

Lung epithelium/E13.5 SP-C-Cre mesenchymal lineages/_Dermol-Cre E12.5-13.5

Kidney epithelium (Wolffian Hoxb7-Cre ducts)/E11.5

Kidney (renal vesicle progenitor cells)/E12.5

Heart (myocardial precursors)/E8.5

Heart (myocardial progenitors and early pharyngeal endoderm)/E8

Hear (proepicardum)/ E9.5

Heart (myocardial precursors)/E9.5

Heart (second heart field cells) /E-8 -E9.5

MesP1-Cre

Pancreatic epithelium/E8.5 Six2-GFP-Cre

Nkx2.5-Cre

Islet1-Cre

\section{GATA5-Cre}

SM22-Cre

MesP1-Cre

Pdx1-Cre
Premature cell cycle withdrawal of neural progenitors

Limb malformation

Impaired radial migration, decreased proliferation

Failure of node formation \& multiple hearts

Limb truncation, overall failure to develop bone

Loss of apical ectodermal ridge

Failure of follicle morphogenesis

Lethal E11.5-13; vascular fragility, impaired

development of the heart septum; impaired endocardial cushion formation

Impaired development of peripheral lung

Synovial joint fusions; abnormal differ

osteoblasts and chondrocytes; increased

chondrogenesis and ectopic cartilage formation

Impaired lung growth and loss of lung muscle progenitors

Premature differentiation, kidney aplasia or hypoplasia

Reduced nephron formation; reduced kidney size and branching

Lethal at E12.5, impaired cardiac development, smaller right ventricles

Lethal E13; dilated outflow tract; smaller right ventricles; pharyngeal arch defects

Lethal around E15.5; impaired cardiac growth and (Zamora et al. 2007) coronary artery formation

Lethal E10.5-11.5; loss of right heart

(Cohen et al. 2007)

Disrupted cardiac looping; shortened heart

(Klaus et al. 2007) outflow tract

Heart outflow tract defects; right ventricle defects (Ai et al. 2007) Acute edematous pancreatitis

Dessimoz et al. 2005) 


\section{$\&_{\mathrm{CSH}}^{\infty}$ Cold Spring Harbor Perspectives in Biology \\ \$EDSO www.cshperspectives.org}

\begin{tabular}{|c|c|c|c|c|}
\hline Gene & Tissue/Time & $\mathrm{Cre}^{\mathrm{a}}$ & Phenotype & Ref. \\
\hline$\gamma$-catenin/plakoglobin & Zygote & & $\begin{array}{l}\text { Lethal at E12-E17; cardiac rupture, skin blistering, } \\
\text { absence of desmosomes in heart, but not in } \\
\text { epithelial tissues }\end{array}$ & $\begin{array}{l}\text { (Bierkamp et al. 1996; Ruiz } \\
\text { et al. 1996) }\end{array}$ \\
\hline \multirow[t]{3}{*}{ p120-catenin } & Epidermis/E11.5 & K14-Cre & $\begin{array}{l}\text { Epidermal hyperplasia and neoplasia and chronic } \\
\text { inflammation }\end{array}$ & $\begin{array}{l}\text { (Perez-Moreno et al. 2006; } \\
\quad \text { Perez-Moreno et al. 2008) }\end{array}$ \\
\hline & $\begin{array}{l}\text { Salivary gland epithelium/ } \\
\text { E14 }\end{array}$ & MMTV-Cre & High grade intraepithelial neoplasia & (Davis and Reynolds 2006) \\
\hline & Dorsal forebrain/E9 & Emx1-Cre & $\begin{array}{l}\text { Reduced spine and synapse densities along } \\
\text { dendrites }\end{array}$ & (Elia et al. 2006) \\
\hline
\end{tabular}

Note, detailed information on gain-of-function and loss-of-function $\beta$-catenin mutant mice can be found in (Grigoryan et al. 2008).

E, embryonic day.

${ }^{\mathrm{a}} \mathrm{Cre}$ is a site-specific recombinase used for gene deletion. 
Adhesive and Signaling Functions of Cadherins and Catenins

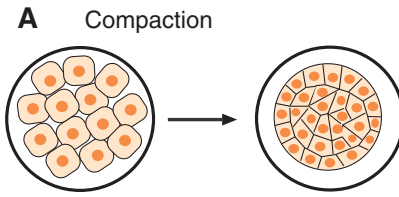

C Neurulation and somitogenesis Pre-segmented

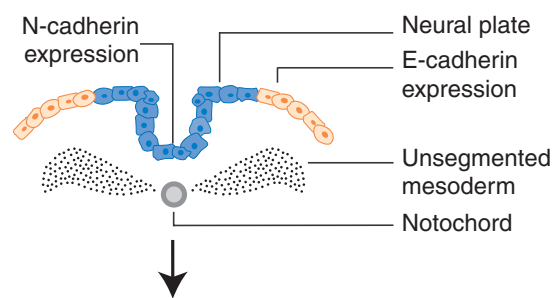

New somites

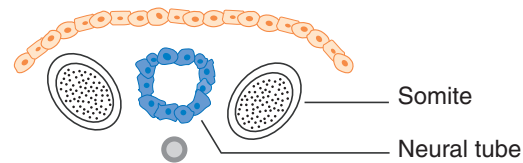

$\downarrow$

Maturing somites

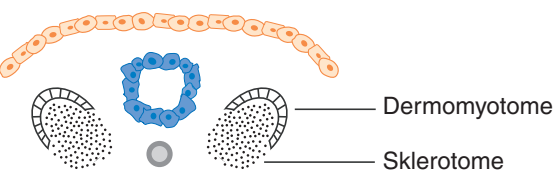

E

Tissue morphogenesis: maintenance of cell polarity /orientation of mitotic spindle

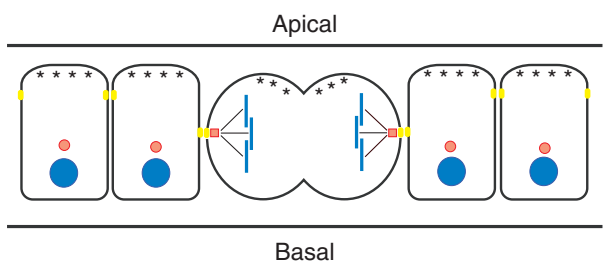

B Convergent extension during gastrulation

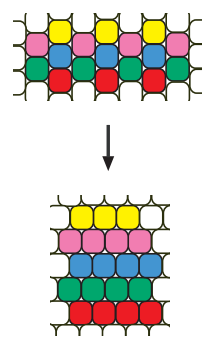

D Neural crest morphogenesis
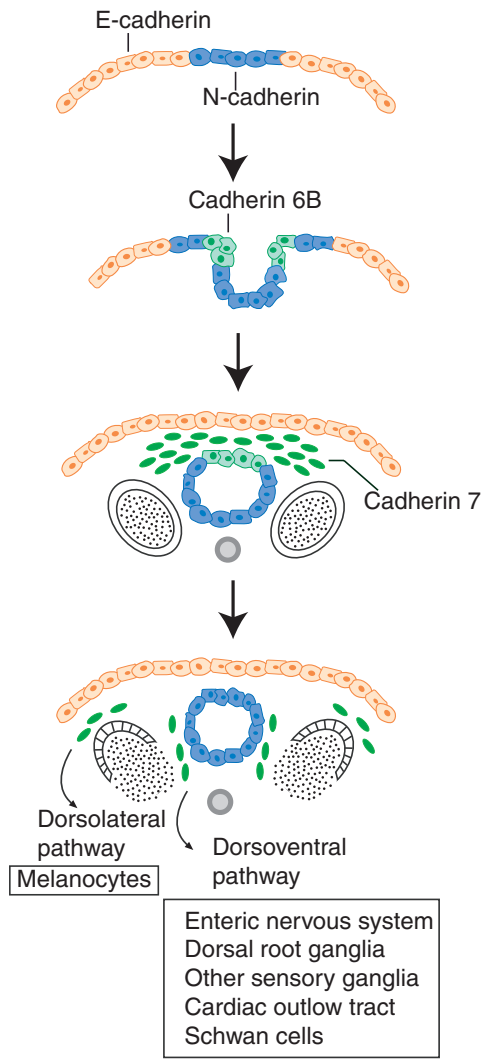

Figure 2. Cadherin-catenin complexes and major developmental events. (A) Functional cadherin-catenin adhesion is required for embryonic compaction during early preimplantation development, as well as multiple later morphogenetic events involving mesenchymal-to-epithelial transition. $(B)$ Cadherin-catenin system and p120-catenin-mediated planar cell polarity signaling are required for embryonic gastrulation and "convergent extension," which results in lengthening of the embryonic body axis. $(C)$ Cadherin-catenin adhesion is involved in tissue segregation and neural tube formation (neurulation), as well as formation of somites. (D) Down-regulation of cadherin-catenin adhesion (epithelial-to-mesenchymal transition) is necessary for emigration of neural crest cells from the neural tube and their subsequent migration. A reverse process of mesenchymal-to-epithelial transition is required for neural crest cell-derived structure formation, when neural crest cells reach their target locations. (E) Cadherin-catenin complexes are necessary to orient mitotic spindles of dividing cells to maintain proper tissue morphology. 
indicates that $\alpha \mathrm{E}$-catenin is an indispensable component of the AJ complex. Although early embryonic phenotypes of E-cadherin- and $\alpha E$-catenin-deficient mutants are adhesiondependent, they clearly contrast with the phenotypes of $\beta$-catenin-null embryos, which seem to be adhesion-independent and rather result from $\beta$-catenin's signaling roles at later stages of development during embryonic gastrulation (Haegel et al. 1995; Huelsken et al. 2000). This is likely because of a compensatory effect of plakoglobin, and this hypothesis is supported by increased localization of plakoglobin to the lateral membrane of trophectodermal epithelial cells in $\beta$-catenin ${ }^{-/-}$ embryos (Haegel et al. 1995).

\section{Gastrulation, Embryo Patterning, and Somitogenesis}

During gastrulation, the morphology of the newly formed embryo is dramatically restructured to form three embryonic germ layers (endoderm, ectoderm, and mesoderm) that will give rise to all tissues and organs in the developing organism. At the onset of gastrulation, cells of the epiblast migrate through the primitive streak to position the embryonic germ layers, and these morphogenetic movements are facilitated by the process of epithelial-mesenchymal transition (EMT), in which AJs play a fundamental role. During murine gastrulation, E-cadherin is down-regulated in the primitive streak as cells undergo embryonic EMT and this downregulation is necessary for proper gastrulation and mesoderm cell fate specification in the mouse embryo (Burdsal et al. 1993; Ciruna and Rossant 2001).

Down-regulation of E-cadherin function is accomplished by multiple mechanisms including transcriptional repression via fibroblast growth factor/fibroblast growth factor receptor 1 (FGF/FGFR1)-dependent induction of Snail (Ciruna and Rossant 2001), downregulation of E-cadherin protein levels by $\mathrm{p} 38$ mitogen-activated protein kinase (MAPK) (Zohn et al. 2006), and disruption of cadherincatenin complexes by EPB41L5, a band 4.1 superfamily protein that interacts with p120-catenin and prevents its association with cadherin (Hirano et al. 2008). An additional pathway involving controlled internalization of cadherin was recently discovered in Xenopus (Ogata et al. 2007). TGF- $\beta$ signaling, which is critical for gastrulation, induces the expression of transmembrane protein fibronectin leucinerich repeat transmembrane 3 (FLRT3) and a small GTPase Rnd1. FLRT3 and Rnd1 interact physically and modulate cell adhesion during gastrulation by controlling dynamin-dependent endocytosis of epithelial cadherin (Ogata et al. 2007). Interestingly, mesodermal cells formed during gastrulation down-regulate E-cadherin and increase expression of $\mathrm{N}$-cadherin, which is maintained by platelet-derived growth factor (PDGF) signaling and is required for normal mesodermal cell migration (Yang et al. 2008). Thus, gastrulation is a remarkable example of a naturally occurring cadherin-switch phenomenon, in which expression of one cadherin (E-cadherin) is replaced by another ( $\mathrm{N}$-cadherin), and both of them are required for normal developmental process, although they regulate different aspects of gastrulation.

In addition to EMT, the gastrulating embryo undergoes a significant extension of the body axis through the process known as convergent extension. Convergent extension involves highly organized and coordinated cell movements toward the midline, resulting in cell intercalation and rearrangement of their original positions (Fig. 2B). Morpholinomediated knock down of p120-catenin or ARVCF in Xenopus revealed a critical role of these proteins in the regulation of convergent extension (Paulson et al. 1999; Fang et al. 2004). Subsequent mechanistic analyses indicated that signaling involving activation of Rac, inhibition of RhoA, and modulation of a repressive activity of transcription factor Kaiso on Wnt11 expression were responsible for the phenotypes (Fang et al. 2004; Kim et al. 2004). Intriguingly, Wnt11 is a critical upstream regulator and RhoA is an important downstream target of the planar cell polarity pathway (see McNeill et al. 2009), which is known to be necessary for convergent extension. Thus, 
these experiments identified p120-catenin as an essential regulator of planar cell polarity and revealed at least two independent mechanisms responsible for this function.

Loss-of-function and gain-of-function experiments showed the requirement for $\beta$ catenin in proper patterning of various embryonic structures, tissues, and organs throughout embryonic development (Grigoryan et al. 2008). Although loss of zygotic $\beta$-catenin allows normal blastocyst development, the mutant embryos die shortly thereafter because of major defects in gastrulation, which is characterized by defects in the anteriorposterior axis formation and complete failure of mesoderm and head structure development (Haegel et al. 1995; Huelsken et al. 2000). Remarkably, these defects are not caused by the loss of cell-cell adhesion, which is maintained by plakoglobin, but because of deficiency in canonical Wnt signaling, which plays a critical role in regulation of gastrulation, and many other aspects of early embryonic development (see Cadigan and Peifer 2009; Heuberger and Birchmeier 2009).

In addition to major defects in gastrulation, loss of $\beta$-catenin also severely impairs somitogenesis. Conditional ablation of $\beta$-catenin in the visceral endoderm results in embryos that gastrulate, but are unable to form the node and display the failure of posterior axis elongation, somite formation, and endodermal cell fate specification (Lickert et al. 2002). Remarkably, these mutants show ectopic expression of $\mathrm{Bmp} 2$ in precardiac mesoderm and form multiple hearts. Here, as in many other early embryonic $\beta$-catenin loss-of-function studies, the authors found no defects in intercellular adhesion because of compensatory role of plakoglobin (Lickert et al. 2002). Furthermore, deletion of $\beta$-catenin in mesoderm precursors in the primitive streak blocks paraxial mesoderm formation and results in embryonic axis truncation (Aulehla et al. 2008; Dunty et al. 2008). Interestingly, $\beta$-catenin-mediated signaling is used again during embryonic dorsal-ventral axis specification. In Xenopus, canonical Wnt signaling is activated in dorsal part of the embryo to establish the dorsal axis (Tao et al. 2005). Because of the ancient genome duplication, Zebra fish genome contains two $\beta$-catenin genes. Although $\beta$-catenin-2 is essential for dorsal axis specification early in development, both $\beta$-catenin-1 and -2 are required for posteriorizing signaling required for normal embryonic patterning (Bellipanni et al. 2006). In addition to body patterning, Wnt $/ \beta$-catenin signaling is also critical for the normal limb morphogenesis. Apical ectodermal ridge (AER) is an ectodermal structure overlying and inducing the development of the limb bud during vertebrate morphogenesis. $\beta$-catenin-mediated Wnt signaling lies upstream of the Bmp pathway in establishment of the AER and dorso-ventral limb patterning (Barrow et al. 2003; Soshnikova et al. 2003; Hill et al. 2006).

In summary, loss-of-function and gain-offunction experiments revealed critical roles for E-cadherin, $\mathrm{N}$-cadherin, $\mathrm{p} 120$, and $\beta$-catenins in gastrulation and early embryonic patterning. Although most of the evidence so far points toward adhesive roles for cadherins, these experiments revealed very exciting signaling roles for p120-catenin in planar cell polaritymediated convergent extension and for $\beta$-catenin in a variety of critical developmental decisions during early embryogenesis.

\section{Early Heart and Vascular System \\ Development}

The primitive heart tube undergoes a series of morphological changes including looping into an S-shaped structure that is critical for proper alignment of the cardiac outflow tract. $\mathrm{N}$-cadherin plays a critical role in multiple cardiac cell lineages and at different times during cardiac morphogenesis. Germline deletion of $\mathrm{N}$-cadherin results in mid-gestation lethality associated with multiple developmental abnormalities including severe cardiovascular defects (Radice et al. 1997b). A dramatic cell adhesion defect was observed in the developing myocardium of $\mathrm{N}$-cadherin mutant embryos resulting in a severely deformed heart tube. Interestingly, expression of either $\mathrm{N}$-cadherin or E-cadherin under the control 
of a muscle-specific promoter was able to rescue the cardiac phenotype, demonstrating that these cadherins are interchangeable during cardiac looping morphogenesis (Luo et al. 2001). Chimeric mouse embryos generated from N-cadherin-null embryonic stem cells showed that $\mathrm{N}$-cadherin-mediated adhesion is critical for maintaining cell-cell interactions in tissues undergoing active cellular rearrangements and increased mechanical stress (e.g., primitive heart) (Kostetskii et al. 2001). $\mathrm{N}$-cadherin-deficient and wild-type cardiomyocytes initially intermix in the chimeras; however, the adhesion is short lived as the mutant cells are excluded from the myocardial wall during the transition from a cuboidal cell morphology to a flattened, tightly associated myocardial cell layer (Kostetskii et al. 2001). In addition to mediating cell adhesion, $\mathrm{N}$-cadherin was shown to be involved in the migration of cardiomyocytes toward the endocardium in a process called trabeculation, which results in expansion of the cardiac chambers (Ong et al. 1998). N-cadherin is also involved in heterotypic cell interactions in the developing heart as loss of $\mathrm{N}$-cadherin from the epicardium disrupts epicardial-myocardial cell-cell interactions resulting in a thinned ventricular myocardium (Luo et al. 2006).

Conditional deletion of $\mathrm{N}$-cadherin in endothelial cells revealed an unexpected role for this protein in the developing vascular system (Luo and Radice 2005). Interestingly, the mid-gestation embryonic phenotype of the endothelial-specific N-cadherin knockout embryo bears similarities to the VE-cadherinnull phenotype. Both N-cadherin- and VE-cadherin-deficient endothelial cells are unable to form a normal vascular plexus leading to impaired vasculogenesis. VEcadherin expression was perturbed in the endothelial-specific $\mathrm{N}$-cadherin knockout embryo. In contrast, $\mathrm{N}$-cadherin expression was not affected in VE-cadherin-deficient endothelial cells (Carmeliet et al. 1999). This is the only known example in which one cadherin subtype controls the expression of another, which may reflect complex and dynamic cell-cell rearrangements involved in vascular permeability. In addition to the similarities of endothelial phenotypes in $\mathrm{N}$-cadherin and VE-cadherin mutant embryos, both knockouts show a myocardial cell adhesion defect indicating cadherin-mediated signaling between the endocardium and myocardium (Carmeliet et al. 1999; Luo and Radice 2005).

VE-cadherin itself is critical for a developing vascular system, where it has both mechanical and signaling functions (Carmeliet et al. 1999). Endothelial cells missing VE-cadherin fail to support remodeling and maturation of developing vasculature. In addition to the adhesion defect, these cells also display a prominent decrease in vascular endothelial growth factor receptor-2-phosphatidylinositol 3 kinase (VEGFR-2-PI3K) signaling and subsequent apoptosis (Carmeliet et al. 1999). VE-cadherin also uses a similar PI3K-Akt pathway to up-regulate the expression of claudin-5, which is required for the formation of tight junctions between endothelial cells to prevent vascular permeability (Taddei et al. 2008). Remarkably, although VE-cadherin is necessary for positive regulation of VEGFR2-PI3K signaling and cell survival, it has an opposite effect on VEGFR-2-MAPK signaling and cell proliferation (Grazia Lampugnani et al. 2003). Subsequent analysis revealed a critical role of VE-cadherin in preventing the internalization of activated VEGFR-2 and stimulation of VEGFR-2-MAPK signaling from the endosomal compartment (Lampugnani et al. 2006). In addition to regulation of VEGFR-2, VE-cadherin also binds to all the components of the TGF- $\beta$ receptor complex and promotes TGF- $\beta$ signaling (Rudini et al. 2008). Because TGF- $\beta$ is a major developmental signaling pathway, it is likely that a functional connection between VE-cadherin and TGF- $\beta$ signaling plays an important role in vertebrate morphogenesis.

Plakoglobin is a close relative of $\beta$-catenin, but in contrast to the signaling function of $\beta$-catenin, plakoglobin loss-of-function experiments revealed primarily a structural role for this protein. Plakoglobin is unique in its ability to interact with both classical 
cadherins in AJs and desmosomal cadherins in desmosomes, which are distinct cell-cell adhesion structures linked to the intermediate cytoskeleton. Mice with zygotic disruption of plakoglobin die in utero showing defects in cardiac structural integrity and skin blistering (Bierkamp et al. 1996; Ruiz et al. 1996; Bierkamp et al. 1999). Interestingly, both heart and skin defects were caused by abnormal desmosome function, indicating that $\beta$-catenin cannot functionally substitute for plakoglobin in desmosomes. Therefore, the primary role of plakoglobin is in desmosome function and it is not essential for the function of AJs.

\section{Neural Crest Development}

Both adhesion and signaling activities of cadherin and catenin proteins play a pivotal role in neural crest development. Neural crest cells undergo EMT and migrate from the developing dorsal neural tube ultimately differentiating and forming a wide variety of adult structures such as parts of peripheral nervous system, melanocytes and some craniofacial structures (Fig. 2D). Initial EMT and emigration of neural crest cells from the neural tube requires down-regulation of $\mathrm{N}$-cadherin (Nakagawa and Takeichi 1998), which is achieved by BMP4-induced cleavage of $\mathrm{N}$-cadherin via ADAM10 (a disintegrin and metalloproteinase) (Shoval et al. 2007). Interestingly, this cleavage is not only required to down-regulate the adhesive function of $\mathrm{N}$-cadherin, but it also generates cytoplasmic $\mathrm{N}$-cadherin fragment that translocates to the nucleus and stimulates $\beta$-catenin-mediated transcription. Both adhesive and signaling activities are likely to participate in neural crest emigration. Deletion of $\mathrm{N}$-cadherin from murine neural crest cells using Wnt1-Cre results in aberrant remodeling of the cardiac outflow tract and embryonic lethality (Luo et al. 2006). Cardiac neural crest cells normally elongate and align with their neighbors eventually aggregating at the midline to divide the outflow tract into aortic and pulmonary channels. In Wnt1-Cre-driven N-cadherin mutants, outflow tract cells are rounded and less condensed compared with wild-type cells (Luo et al. 2006). An adhesive function of $\mathrm{N}$-cadherin at the neural crest cell migration target site was also shown for sympathetic ganglia (Kasemeier-Kulesa et al. 2006).

$\beta$-catenin plays a pivotal role in neural crest specification. Ablation of $\beta$-catenin in mouse embryos using Wnt1-Cre results in the failure of craniofacial development and loss of melanocyte and sensory neural cell lineages (Brault et al. 2001; Hari et al. 2002). This is reminiscent of the phenotype observed in conventional Wnt1 knockout mice (McMahon and Bradley 1990), indicating that $\beta$-catenin signaling function is required for these developmental processes.

P120-catenin has a major impact on migration of neural crest cells. Knockdown of p120-catenin in developing Xenopus embryos affects the migration of neural crest cells into the branchial arches, and causes defects in eye formation as well as several craniofacial cartilage structures (Ciesiolka et al. 2004). Importantly, defects induced by p120 depletion can be rescued by expression of either dominant-negative Rac or LIM kinase, indicating the involvement of p120-catenin in Rho GTPases signaling during development (Ciesiolka et al. 2004). Therefore, similar to its role in gastrulation, p120-catenin impacts neural crest morphogenesis by regulating Rho-family GTPases and the actin cytoskeleton.

\section{Central Nervous System (CNS) \\ Development}

During formation of the neural plate, the precursor of the vertebrate neural system, Ecadherin expression is replaced by $\mathrm{N}$-cadherin, which continues to be expressed at high levels in all neural tissues throughout the development (Fig. 2C). Knockout of N-cadherin in the developing mouse embryo results in severe malformation of the neural tube (Radice et al. 1997b). Concurrent heart defects and early embryonic death complicated the analysis of $\mathrm{N}$-cadherin-null mice; however, loss-of-function $\mathrm{N}$-cadherin experiments in zebrafish revealed impaired neuroectodermal 
cell adhesion and severely compromised cell movements during neurulation, which ultimately affected neuronal positioning and axon pathfinding (Lele et al. 2002). Interestingly, loss of N-cadherin in zebra fish destabilized membrane-associated $\beta$-catenin and caused increased mitoses in the dorsal midbrain and hindbrain, suggesting an additional signaling role for $\mathrm{N}$-cadherin in this context (Lele et al. 2002). ACNS-specific role of mouse $\mathrm{N}$-cadherin has been analyzed recently using a conditional gene knockout approach (Kadowaki et al. 2007). Deletion of N-cadherin in the developing cerebral cortex results in a massive cortical disorganization and scattering of mitotic cells throughout the cortex (Fig. 3) (Kadowaki et al. 2007). Future studies will likely analyze the potential changes in cell proliferation and cell death in these mutant animals.

Both $\alpha \mathrm{E}$ - and $\alpha \mathrm{N}$-catenins are expressed in the developing mammalian brain; however, their expression patterns are different. $\alpha$ E-catenin is predominantly expressed in neural progenitors and $\alpha \mathrm{N}$-catenin in differentiated neurons. Conditional deletion of $\alpha E$-catenin in neural progenitors resulted in loss of cell adhesion and polarity, which caused severe brain disorganization (Fig. 3) (Lien et al. 2006b). In addition to these mechanical defects, mutant brains also displayed shortening of the cell cycle and decreased apoptosis, which caused an abnormal increase of total brain cell number. Analyses of potential mechanisms identified abnormal activation of Hedgehog (Hh) signaling in hyperplastic dorsal brain structures of $\alpha$ E-catenin-null brains (Lien et al. 2006b). Because Hh signaling and cell proliferation were impacted only in dorsal, but not in the ventral part of $\alpha \mathrm{E}$-catenin-null brains, it is likely that this intriguing connection between $\alpha \mathrm{E}$-catenin and Hh signaling is modulated by other pathways, whose identity and mechanism of action will have to be discovered in future research.
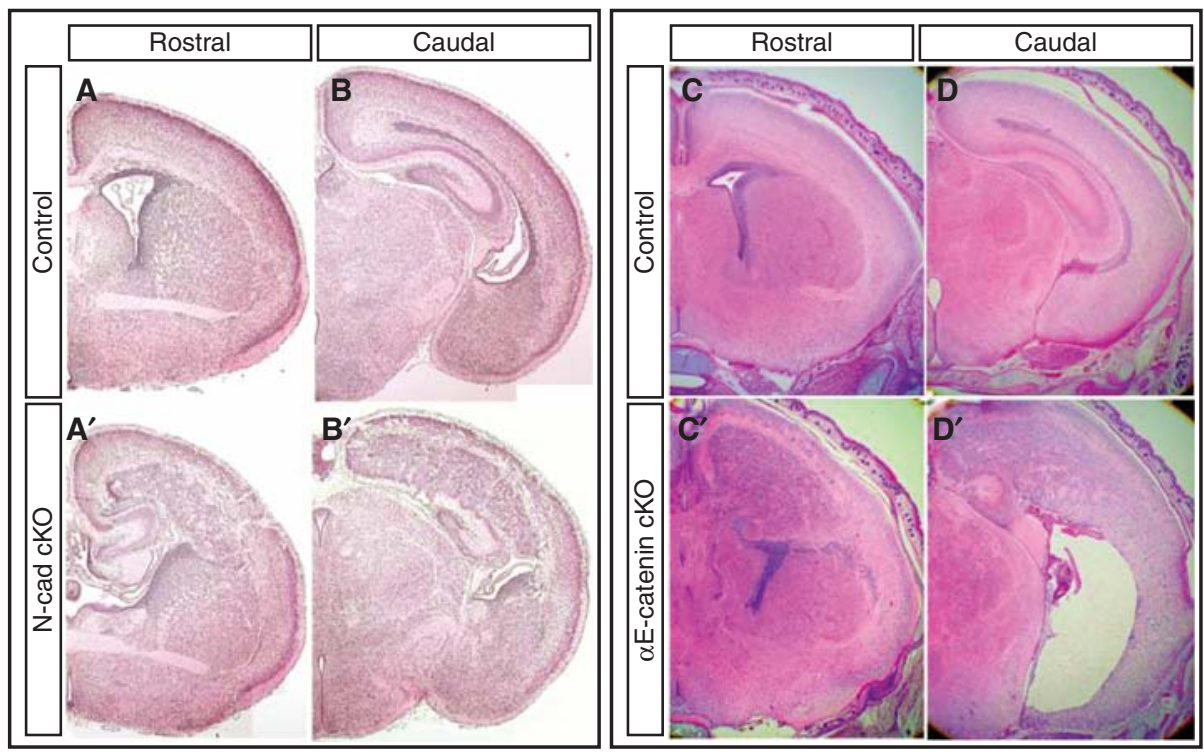

Figure 3. Cadherin-catenin complexes in embryonic brain development. $\left(A-B^{\prime}\right)$ Cortical disorganization in mice with embryonic brain-specific knockout of $\mathrm{N}$-cadherin ( $\mathrm{N}$-cad $\mathrm{cKO}$ ). Hematoxylin and eosin staining of coronal brain sections from one-day-old control $(A, B)$ and D6-Cre N-cadherin cKO pups $\left(\mathrm{A}^{\prime}, \mathrm{B}^{\prime}\right)$. (Reprinted with permission from Kadowaki et al. 2007, copyright 2007 Elsevier.) (C- $\left.D^{\prime}\right)$ Brain disorganization and hyperplasia in mice with embryonic brain-specific knockout of $\alpha$ E-catenin. Hematoxylin and eosin staining of coronal brain sections from new-born control $(C, D)$ and Nestin-Cre $\alpha$ E-catenin cKO pups $\left(C^{\prime}, D^{\prime}\right)$. (Reprinted, with permission, from Lien et al. 2006b, copyright 2006 American Association for the Advancement in Science.) 
Although $\alpha$ E-catenin is essential for early embryonic development, zygotic $\alpha \mathrm{N}$-cateninnull mice survive into adulthood; however, they display a prominent neurological phenotype. These animals show ataxia and their brains display underdevelopment and disorganization of the cerebellum (Park et al. 2002a,b).

Both adhesive and signaling activities of $\beta$-catenin play critical roles in the developing CNS. Conditional ablation of $\beta$-catenin in the murine forebrain early in development results in cell fate changes and ventralization of telencephalon (Backman et al. 2005). $\beta$-catenin is critical for normal cell-cell adhesion in neuroepithelial cells and conditional deletion of $\beta$-catenin in developing forebrain results in breakdown of neuroepithelial structures, an increase in apoptosis and loss of the entire forebrain and anterior facial structures (Junghans et al. 2005). Later in brain development, $\beta$-catenin is necessary for self-renewal and maintenance of neuronal progenitors (Machon et al. 2003; Zechner et al. 2003).

\section{Epidermal Development}

Functions of epithelial cadherin-catenin proteins were extensively studied in developing mouse epidermis. Loss-of-function mutants of cadherins, p120-, $\beta$-, and $\alpha$ E-catenins in skin epidermis offer an unprecedented opportunity for side-by-side comparison of the role of different members of cadherin-catenin complexes in the same tissue. These murine models taught us that cadherin-catenin proteins are required not only for cell-cell adhesion, but also for cellular proliferation and differentiation. Although cadherins seem to be mainly involved in the maintenance of the overall mechanical epidermal integrity and protection from apoptosis, catenins play a dual role; on the one hand they act as cadherin stabilizers during AJs formation, on the other hand they function as regulators of cellular signaling pathways (Fig. 4).

The principal cadherin responsible for AJ formation in epithelial cells is E-cadherin.
Intriguingly, however, deletion of E-cadherin in embryonic skin epidermis did not result in a significant impairment of AJs, most likely because of compensatory up-regulation of P-cadherin (Young et al. 2003; Tinkle et al. 2004; Tunggal et al. 2005). The potential compensatory mechanism between E- and P-cadherin in the developing skin has recently been addressed by a study in which the conditional knockout approach was elegantly combined with transgenic shRNA technology to simultaneously ablate E-cadherin and knockdown P-cadherin (E-cad ${ }^{-/-} / P$-cad ${ }^{K D}$ mice) in the epidermal compartment (Tinkle et al. 2008). This resulted in the generation of mutant mice missing all major cadherins in skin epidermis and provided a first look at the epithelial tissue without classical cadherins. $E$-cad ${ }^{-/-} / P$-cad ${ }^{K D}$ epidermis displays loss of AJs, prominent disruption of intercellular adhesion and increase in apoptotic cell death (Tinkle et al. 2008). The cell-cell adhesion defects in $E-c^{-1-} / P-c a d^{K D}$ epidermis were similar to the defects in $\alpha$ E-catenin-deficient epidermis (Vasioukhin et al. 2001). Remarkably, however, in addition to the mechanical defects, the $\alpha$ E-catenin-deficient epidermis also showed an increase in cell proliferation and abnormal activation of Ras-MAPK and NFкB signaling pathways (Vasioukhin et al. 2001; Kobielak and Fuchs 2006). The increase in cell proliferation and activation of MAPK and NFкB pathways were also observed in p120-catenin-deficient epidermis (Perez-Moreno et al. 2006; Perez-Moreno et al. 2008). Moreover, when wild-type keratinocytes are transplanted to the backs of nude mice, they form normal skin epidermis. In contrast, transplanted $\alpha \mathrm{E}$ - and p120-catenin-deficient keratinocytes display disorganization, inflammation and grow in a pattern resembling squamous cell carcinoma. Interestingly, inhibition of NFкB signaling in these transplants resulted in loss of $\alpha \mathrm{E}$-catenin-null cells and a decrease in proliferation of p120-catenin-null cells, indicating an important role of inflammatory pathways in the growth of these mutant cells in vivo (Kobielak and Fuchs 2006; Perez-Moreno et al. 2006). 
E. Stepniak, G.L. Radice, and V. Vasioukhin
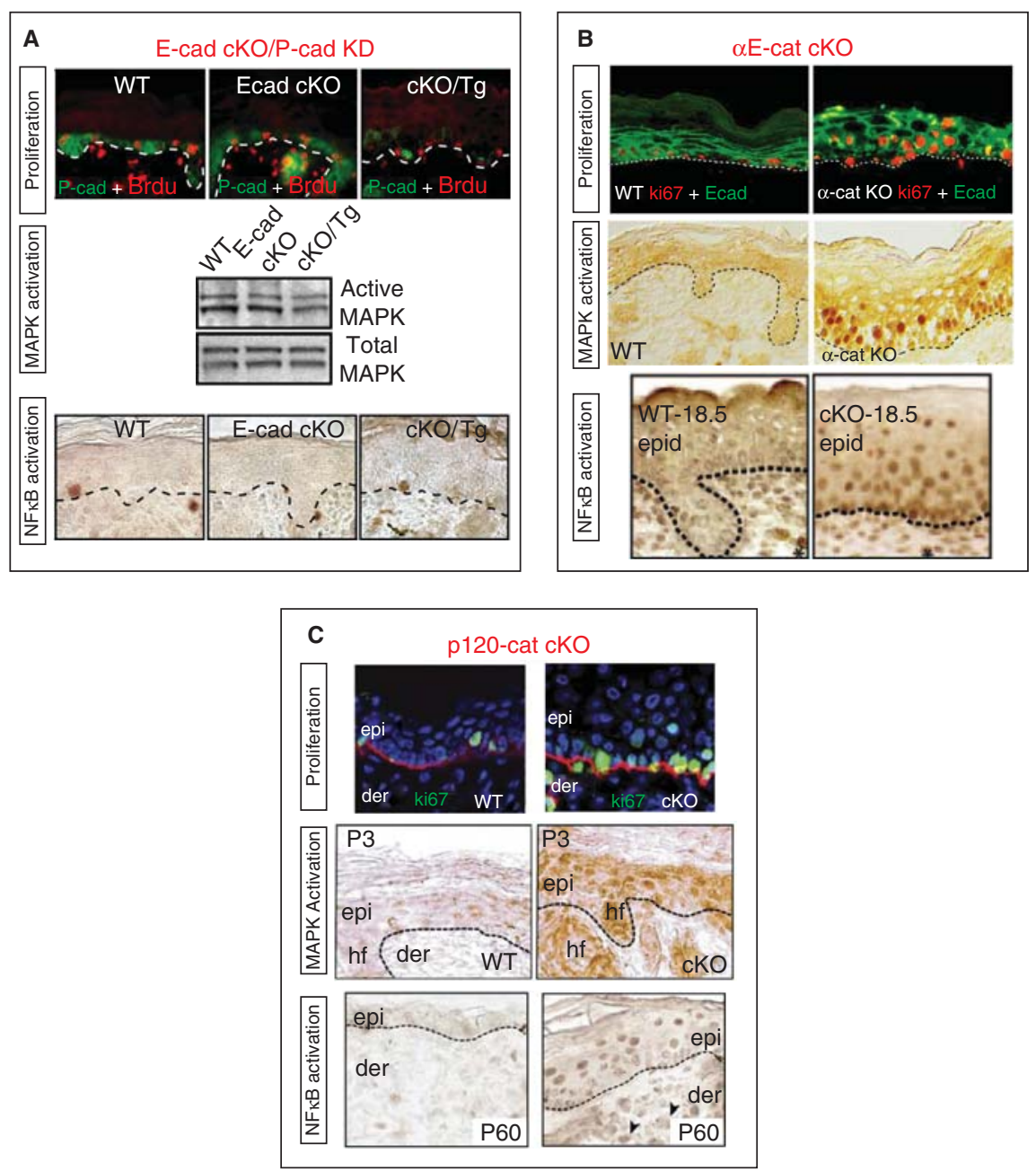

Figure 4. Overlapping and distinct functions of cadherin-catenin proteins in embryonic skin development. $(A)$ Disruption of epidermal integrity, but normal proliferation, MAPK and NFKB signaling pathways in mice with embryonic epidermis-specific deficiency for E-cadherin (E-cad cKO), or both E- and P-cadherins (cKO/Tg). Proliferation was measured by BrdU incorporation (red). P-cadherin staining is shown in green channel. MAPK activity was measured by immunoblotting of total protein extracts with indicated antibodies. NFKB activity was revealed by staining with anti-phospho-NFKB antibodies. (Reprinted with permission from Tinkle et al. 2008, copyright 2008 National Academy of Sciences.) (B) Increase in proliferation, MAPK and NFKB signaling in mice with embryonic epidermis-specific deletion of $\alpha \mathrm{E}$-catenin ( $\alpha \mathrm{E}-\mathrm{cat} \mathrm{cKO})$. Proliferation was measured by staining with anti-Ki67 antibodies (red). E-cadherin staining is shown in green channel. MAPK activity was measured by staining with anti-phospho-Erk1/2 antibodies. NFKB activity was revealed as described in $(A)$. (Proliferation and MAPK panels reprinted from Vasioukhin et al. 2001, copyright 2001 Elsevier.) (NFкB panel reprinted with permission from Kobielak and Fuchs 2006, copyright 2006 National Academy of Sciences.) (C) Increase in proliferation, MAPK and NFкB signaling in mice with embryonic epidermis-specific deficiency for p120-catenin (p120-cat cKO). Proliferation was measured by staining with anti-Ki67 antibodies (green). $\beta 4$-integrin staining is shown in red channel. MAPK and $\mathrm{NF \kappa B}$ activities were revealed as described in $(B)$. (Reprinted with permission from Perez-Moreno et al. 2006, copyright 2006 Elsevier.) 
Because $\beta$-catenin is a prominent member of cadherin-catenin complexes, it would be logical to hypothesize that $\beta$-catenin becomes hyperactivated in $\alpha \mathrm{E}$ - and p120-catenindeficient cells and this may be responsible for hyperplasia in $\alpha \mathrm{E}$ - and p120-catenin-null skin epidermis. However, loss of $\alpha \mathrm{E}$-catenin in skin epidermis did not affect $\beta$-catenin-dependent signaling (Vasioukhin et al. 2001), and this is in agreement with a recent study on the role of $\alpha$ E-catenin in the developing mammalian brain, which also found no changes in $\beta$-catenin transcriptional activity in $\alpha$ E-catenin-null neural progenitors (Lien et al. 2008). Therefore, functions of $\alpha \mathrm{E}$-catenin in regulation of cell proliferation is likely to be $\beta$-catenin-independent.

In contrast to p120- and $\alpha \mathrm{E}$-catenin, loss of $\beta$-catenin in the developing skin did not affect the integrity of the AJs, because of potential compensation by plakoglobin, but it resulted in the failure of proper hair follicle stem cell differentiation and loss of hair follicles (Huelsken et al. 2001). Although changes in cell proliferation, NFKB, and MAPK signaling in $\beta$-catenin-null epidermis have not been reported, $\beta$-catenin was required for maintenance of skin cancer stem cells, indicating that certain level of $\beta$-catenin activity is probably necessary for skin tumorigenesis (Malanchi et al. 2008). Moreover, epidermis-specific overexpression of stabilized, degradation resistant $\beta$-catenin is tumorigenic and results in hair follicle tumor formation (Gat et al. 1998). Therefore, it appears that $\alpha$ E-catenin, p120catenin, and $\beta$-catenin have opposite functions in the regulation of epidermal cell proliferation. Although $\alpha \mathrm{E}$ - and p120-catenins suppress in vivo cell proliferation, $\beta$-catenin promotes uncontrolled cell accumulation and causes cancer.

\section{CONCLUSION AND PERSPECTIVES}

Owing to extensive loss- and gain-of-function genetic analyses, it is now very clear that cadherin-catenin complexes play pivotal roles in multiple aspects of vertebrate development. These genetic studies accumulated significant evidence that besides their essential role in mechanical adhesion, cadherin-catenin proteins regulate signaling pathways important for such fundamental processes as cell division, migration, differentiation, and apoptosis. Intriguing connections between cadherincatenin proteins and major developmental signaling networks led to a hypothesis that cells may use cadherin-catenin complexes as biosensors, which may provide them with information about the immediate external cellular microenvironment (Lien et al. 2006a). Indeed, from the individual cell point of view, neighbor-mediated clustering of cadherincatenin complexes at a specific position of the plasma membrane provides information about the spatial localization of its immediate neighbors. This information may then be used to orient intracellular structures and maintain cellular polarity (Fig. 5). Thus, AJs may provide a vital link between cell polarity and three-dimensional polarity of the tissue, and help cells to exchange information and coordinate their activities as they build organs and tissues during development. Although this hypothesis is very attractive and we now know the major signaling networks affected by cadherin-catenin proteins, there are major gaps in our understanding of how cadherincatenin complexes can transmit information from outside to inside the cell. Some of the possible scenarios include competition for protein availability between the junctional and cytoplasmic or nuclear pools; for example, competition between AJs and nucleus for $\beta$-catenin (Sehgal et al. 1997; Simcha et al. 1998; Gottardi et al. 2001; Onder et al. 2008). An alternative mechanism may involve a direct interaction and regulation of multiple growth factor receptors by cadherin-catenin complexes (Takahashi and Suzuki 1996; Qian et al. 2004; Perrais et al. 2007). Many questions remain unanswered. Is the function of the cadherin-catenin complex in adhesion really connected to its function in cell signaling, or do these proteins have multiple independent functions? How exactly is adhesion information converted into signaling information? How are connections between AJs and signaling 

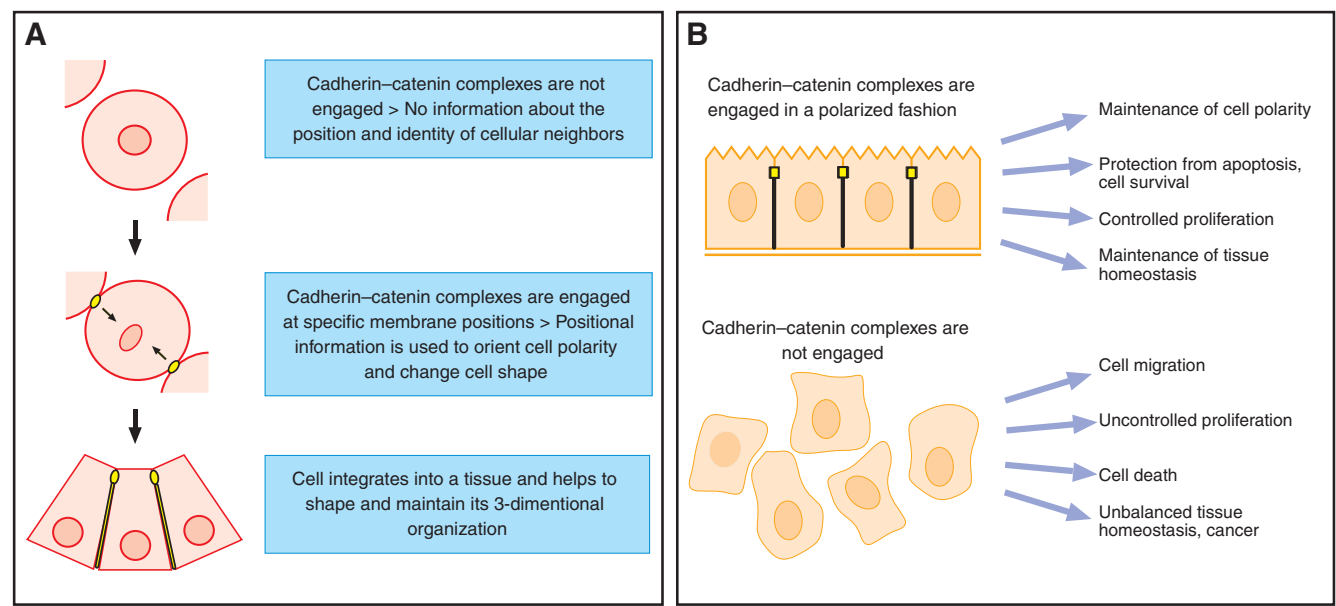

Figure 5. Hypothetical role of cadherin-catenin complexes as biosensors of external cellular environment. (A) Engagement and clustering of cadherin-catenin complexes at a specific position of the inner plasma membrane provides cell with information about the spatial position of its neighbors. This information may be translated into changes in apical-basal and planar cell polarity axes to integrate the cell with its neighbors and form 3-dimentional tissue. (B) Engaged and polarized cadherin-catenin complexes regulate cell polarity, survival and proliferation to control cell behavior and physically and functionally integrate cells into a tissue. Failure to form and cluster cadherin-catenin complexes in a wound or during tissue morphogenesis cause major cell-type-specific changes that may include migration and proliferation (to repair the wound), or cell death (to prevent an ectopic tissue formation).

pathways modulated by embryonic tissueand region-specific microenvironment? Future research should help to answer these important questions.

\section{ACKNOWLEDGMENTS}

This work was supported by National Institute of Health (NIH) grants CA098161 (VV) and HL081569 (GLR).

\section{REFERENCES}

Abe K, Takeichi M. 2008. EPLIN mediates linkage of the cadherin catenin complex to F-actin and stabilizes the circumferential actin belt. Proc Natl Acad Sci 105: 13-19.

Aberle H, Butz S, Stappert J, Weissig H, Kemler R, Hoschuetzky H. 1994. Assembly of the cadherincatenin complex in vitro with recombinant proteins. J Cell Sci 107: 3655-3663.

Ai D, Fu X, Wang J, Lu MF, Chen L, Baldini A, Klein WH, Martin JF. 2007. Canonical Wnt signaling functions in second heart field to promote right ventricular growth. Proc Natl Acad Sci 104: 9319-9324.

Aulehla A, Wiegraebe W, Baubet V, Wahl MB, Deng C, Taketo M, Lewandoski M, Pourquie O. 2008. A $\beta$-catenin gradient links the clock and wavefront systems in mouse embryo segmentation. Nat Cell Biol 10: $186-193$.

Backman M, Machon O, Mygland L, van den Bout CJ, Zhong W, Taketo MM, Krauss S. 2005. Effects of canonical Wnt signaling on dorso-ventral specification of the mouse telencephalon. Dev Biol 279: 155-168.

Barrow JR, Thomas KR, Boussadia-Zahui O, Moore R, Kemler R, Capecchi MR, McMahon AP. 2003. Ectodermal Wnt $3 / \beta$-catenin signaling is required for the establishment and maintenance of the apical ectodermal ridge. Genes Dev 17: 394-409.

Battle MA, Konopka G, Parviz F, Gaggl AL, Yang C, Sladek FM, Duncan SA. 2006. Hepatocyte nuclear factor $4 \alpha$ orchestrates expression of cell adhesion proteins during the epithelial transformation of the developing liver. Proc Natl Acad Sci 103: 8419-8424.

Bellipanni G, Varga M, Maegawa S, Imai Y, Kelly C, Myers AP, Chu F, Talbot WS, Weinberg ES. 2006. Essential and opposing roles of zebrafish $\{\beta\}$-catenins in the formation of dorsal axial structures and neurectoderm. Development 133: 1299-1309.

Bierkamp C, McLaughlin KJ, Schwarz H, Huber O, Kemler R. 1996. Embryonic heart and skin defects in mice lacking plakoglobin. Dev Biol 180: 780-785.

Bierkamp C, Schwarz H, Huber O, Kemler R. 1999. Desmosomal localization of $\beta$-catenin in the skin of plakoglobin null-mutant mice. Development 126: 371-381.

Boussadia O, Kutsch S, Hierholzer A, Delmas V, Kemler R. 2002. E-cadherin is a survival factor for the lactating mouse mammary gland. Mech Dev 115: 53-62. 
Brault V, Moore R, Kutsch S, Ishibashi M, Rowitch DH, McMahon AP, Sommer L, Boussadia O, Kemler R. 2001. Inactivation of the $\beta$-catenin gene by Wnt1-Cremediated deletion results in dramatic brain malformation and failure of craniofacial development. Development 128: 1253-1264.

Brembeck FH, Schwarz-Romond T, Bakkers J, Wilhelm S, Hammerschmidt M, Birchmeier W. 2004. Essential role of BCL9-2 in the switch between $\beta$-catenin's adhesive and transcriptional functions. Genes Dev 18: 2225-2230.

Brembeck FH, Rosario M, Birchmeier W. 2006. Balancing cell adhesion and Wnt signaling, the key role of $\beta$-catenin. Curr Opin Genet Dev 16: 51-59.

Bridgewater D, Cox B, Cain J, Lau A, Athaide V, Gill PS, Kuure S, Sainio K, Rosenblum ND. 2008. Canonical $\mathrm{WNT} / \beta$-catenin signaling is required for ureteric branching. Dev Biol 317: 83-94.

Burdsal CA, Damsky CH, Pedersen RA. 1993. The role of E-cadherin and integrins in mesoderm differentiation and migration at the mammalian primitive streak. Development 118: 829-844.

Cadigan KM, Peifer M. 2009. Wnt signaling from development to disease: Insights from model systems. Cold Spring Harb Perspect Biol 1: a002881.

Carmeliet P, Lampugnani MG, Moons L, Breviario F, Compernolle V, Bono F, Balconi G, Spagnuolo R, Oostuyse B, Dewerchin M, et al. 1999. Targeted deficiency or cytosolic truncation of the VE-cadherin gene in mice impairs VEGF-mediated endothelial survival and angiogenesis. Cell 98: 147-157.

Cattelino A, Liebner S, Gallini R, Zanetti A, Balconi G, Corsi A, Bianco P, Wolburg H, Moore R, Oreda B, et al. 2003. The conditional inactivation of the $\beta$-catenin gene in endothelial cells causes a defective vascular pattern and increased vascular fragility. J Cell Biol 162: 1111-1122.

Ciesiolka M, Delvaeye M, Van Imschoot G, Verschuere V, McCrea P, van Roy F, Vleminckx K. 2004. p120 catenin is required for morphogenetic movements involved in the formation of the eyes and the craniofacial skeleton in Xenopus. J Cell Sci 117: 4325-4339.

Cavey M, Lecuit T. 2009. Molecular bases of cell-cell junctions stability and dynamics. Cold Spring Harb Perspect Biol 1: a002998.

Ciruna B, Rossant J. 2001. FGF signaling regulates mesoderm cell fate specification and morphogenetic movement at the primitive streak. Dev Cell 1: 37-49.

Claverie JM, Hardelin JP, Legouis R, Levilliers J, Bougueleret L, Mattei MG, Petit C. 1993. Characterization and chromosomal assignment of a human cDNA encoding a protein related to the murine $102-\mathrm{kDa}$ cadherinassociated protein ( $\alpha$-catenin). Genomics 15: 13-20.

Clevers H. 2006. Wnt $/ \beta$-catenin signaling in development and disease. Cell 127: 469-480.

Cohen ED, Wang Z, Lepore JJ, Lu MM, Taketo MM, Epstein DJ, Morrisey EE. 2007. Wnt/ $\beta$-catenin signaling promotes expansion of Isl-1-positive cardiac progenitor cells through regulation of FGF signaling. The Journal of clinical investigation 117: 1794-1804.

Coluccia AM, Benati D, Dekhil H, De Filippo A, Lan C, Gambacorti-Passerini C. 2006. SKI-606 decreases growth and motility of colorectal cancer cells by preventing pp60(c-Src)-dependent tyrosine phosphorylation of $\beta$-catenin and its nuclear signaling. Cancer Res 66: 2279-2286.

Coluccia AM, Vacca A, Dunach M, Mologni L, Redaelli S, Bustos VH, Benati D, Pinna LA, Gambacorti-Passerini C. 2007. Bcr-Abl stabilizes $\beta$-catenin in chronic myeloid leukemia through its tyrosine phosphorylation. Embo J 26: 1456-1466.

Dahl U, Sjodin A, Larue L, Radice GL, Cajander S, Takeichi M, Kemler R, Semb H. 2002. Genetic dissection of cadherin function during nephrogenesis. Mol Cell Biol 22: 1474-1487.

Daugherty RL, Gottardi CJ. 2007. Phospho-regulation of $\beta$-catenin adhesion and signaling functions. Physiology (Bethesda) 22: 303-309.

Davis MA, Reynolds AB. 2006. Blocked acinar development, E-cadherin reduction, and intraepithelial neoplasia upon ablation of p120-catenin in the mouse salivary gland. Dev Cell 10: 21-31.

Day TF, Guo X, Garrett-Beal L, Yang Y. 2005. Wnt/ $\beta$-catenin signaling in mesenchymal progenitors controls osteoblast and chondrocyte differentiation during vertebrate skeletogenesis. Dev Cell 8: 739-750.

De Langhe SP, Carraro G, Tefft D, Li C, Xu X, Chai Y, Minoo P, Hajihosseini MK, Drouin J, Kaartinen V, et al. 2008. Formation and differentiation of multiple mesenchymal lineages during lung development is regulated by $\beta$-catenin signaling. PLoS ONE 3: e1516.

De Vries WN, Evsikov AV, Haac BE, Fancher KS, Holbrook AE, Kemler R, Solter D, Knowles BB. 2004. Maternal $\beta$-catenin and E-cadherin in mouse development. Development 131: 4435-4445.

Dessimoz J, Bonnard C, Huelsken J, Grapin-Botton A. 2005. Pancreas-specific deletion of $\beta$-catenin reveals Wntdependent and Wnt-independent functions during development. Curr Biol 15: 1677-1683.

Drees F, Pokutta S, Yamada S, Nelson WJ, Weis WI. 2005. $\alpha$-catenin is a molecular switch that binds E-cadherin$\beta$-catenin and regulates actin-filament assembly. Cell 123: 903-915.

Dunty WC Jr, Biris KK, Chalamalasetty RB, Taketo MM, Lewandoski M, Yamaguchi TP. 2008. Wnt3a/ $\beta$-catenin signaling controls posterior body development by coordinating mesoderm formation and segmentation. Development 135: 85-94.

Elia LP, Yamamoto M, Zang K, Reichardt LF. 2006. p120 catenin regulates dendritic spine and synapse development through Rho-family GTPases and cadherins. Neuron 51: 43-56.

Erez N, Bershadsky A, Geiger B. 2005. Signaling from adherens-type junctions. European journal of cell biology 84: 235-244.

Fang X, Ji H, Kim SW, Park JI, Vaught TG, Anastasiadis PZ, Ciesiolka M, McCrea PD. 2004. Vertebrate development requires ARVCF and p120 catenins and their interplay with RhoA and Rac. J Cell Biol 165: 87-98.

Gat U, DasGupta R, Degenstein L, Fuchs E. 1998. De Novo hair follicle morphogenesis and hair tumors in mice expressing a truncated $\beta$-catenin in skin. Cell 95: 605-614.

Gory-Faure S, Prandini MH, Pointu H, Roullot V, Pignot-Paintrand I, Vernet M, Huber P. 1999. Role of 
vascular endothelial-cadherin in vascular morphogenesis. Development 126: 2093-2102.

Gottardi CJ, Wong E, Gumbiner BM. 2001. E-cadherin suppresses cellular transformation by inhibiting $\beta$-catenin signaling in an adhesion-independent manner. $J$ Cell Biol 153: 1049-1060.

Grazia Lampugnani M, Zanetti A, Corada M, Takahashi T, Balconi G, Breviario F, Orsenigo F, Cattelino A, Kemler R, Daniel TO, et al. 2003. Contact inhibition of VEGF-induced proliferation requires vascular endothelial cadherin, $\beta$-catenin, and the phosphatase DEP-1/CD148. J Cell Biol 161: 793-804.

Grigoryan T, Wend P, Klaus A, Birchmeier W. 2008. Deciphering the function of canonical Wnt signals in development and disease: Conditional loss- and gain-of-function mutations of $\beta$-catenin in mice. Genes Dev 22: 2308-2341.

Haegel H, Larue L, Ohsugi M, Fedorov L, Herrenknecht K, Kemler R. 1995. Lack of $\beta$-catenin affects mouse development at gastrulation. Development 121: 3529-3537.

Hari L, Brault V, Kleber M, Lee HY, Ille F, Leimeroth R, Paratore C, Suter U, Kemler R, Sommer L. 2002. Lineage-specific requirements of $\beta$-catenin in neural crest development. J Cell Biol 159: 867-880.

Hartsock A, Nelson WJ. 2008. Adherens and tight junctions: Structure, function and connections to the actin cytoskeleton. Biochim Biophys Acta 1778: 660-669.

Heuberger J, Birchmeier W. 2009. Interplay of cadherinmediated cell adhesion and canonical Wnt signaling. Cold Spring Harb Perspect Biol 1: a002915.

Hill TP, Spater D, Taketo MM, Birchmeier W, Hartmann C. 2005. Canonical Wnt/ $\beta$-catenin signaling prevents osteoblasts from differentiating into chondrocytes. Dev Cell 8: 727-738.

Hill TP, Taketo MM, Birchmeier W, Hartmann C. 2006. Multiple roles of mesenchymal $\{\beta\}$-catenin during murine limb patterning. Development 133: 1219-1229.

Hirano S, Kimoto N, Shimoyama Y, Hirohashi S, Takeichi M. 1992. Identification of a neural $\alpha$-catenin as a key regulator of cadherin function and multicellular organization. Cell 70: 293-301.

Hirano M, Hashimoto S, Yonemura S, Sabe H, Aizawa S. 2008. EPB41L5 functions to post-transcriptionally regulate cadherin and integrin during epithelialmesenchymal transition. J Cell Biol 182: 1217-1230.

Hollnagel A, Grund C, Franke WW, Arnold HH. 2002. The cell adhesion molecule $\mathrm{M}$-cadherin is not essential for muscle development and regeneration. Mol Cell Biol 22: 4760-4770.

Horikawa K, Radice G, Takeichi M, Chisaka O. 1999. Adhesive subdivisions intrinsic to the epithelial somites. Dev Biol 215: 182-189.

Huelsken J, Vogel R, Brinkmann V, Erdmann B, Birchmeier C, Birchmeier W. 2000. Requirement for $\beta$-catenin in anterior-posterior axis formation in mice. $J$ Cell Biol 148: $567-578$.

Huelsken J, Vogel R, Erdmann B, Cotsarelis G, Birchmeier W. 2001. $\beta$-Catenin controls hair follicle morphogenesis and stem cell differentiation in the skin. Cell 105: 533-545.
Hulpiau P, van Roy F. 2009. Molecular evolution of the cadherin superfamily. Int J Biochem Cell Biol 41: 349-369.

Janssens B, Goossens S, Staes K, Gilbert B, van Hengel J, Colpaert C, Bruyneel E, Mareel M, van Roy F. 2001. $\alpha$ T-catenin: A novel tissue-specific $\beta$-catenin-binding protein mediating strong cell-cell adhesion. J Cell Sci 114: $3177-3188$.

Junghans D, Hack I, Frotscher M, Taylor V, Kemler R. 2005. $\beta$-catenin-mediated cell-adhesion is vital for embryonic forebrain development. Dev Dyn 233: 528-539.

Kadowaki M, Nakamura S, Machon O, Krauss S, Radice GL, Takeichi M. 2007. N-cadherin mediates cortical organization in the mouse brain. Dev Biol 304: 22-33.

Kajiguchi T, Chung EJ, Lee S, Stine A, Kiyoi H, Naoe T, Levis MJ, Neckers L, Trepel JB. 2007. FLT3 regulates $\beta$-catenin tyrosine phosphorylation, nuclear localization, and transcriptional activity in acute myeloid leukemia cells. Leukemia 21: 2476-2484.

Kan NG, Stemmler MP, Junghans D, Kanzler B, de Vries WN, Dominis M, Kemler R. 2007. Gene replacement reveals a specific role for E-cadherin in the formation of a functional trophectoderm. Development 134: 31-41.

Kasemeier-Kulesa JC, Bradley R, Pasquale EB, Lefcort F, Kulesa PM. 2006. Eph/ephrins and N-cadherin coordinate to control the pattern of sympathetic ganglia. Development 133: 4839-4847.

Kawaguchi J, Azuma Y, Hoshi K, Kii I, Takeshita S, Ohta T, Ozawa H, Takeichi M, Chisaka O, Kudo A. 2001. Targeted disruption of cadherin-11 leads to a reduction in bone density in calvaria and long bone metaphyses. $J$ Bone Miner Res 16: 1265-1271.

Kim SW, Park JI, Spring CM, Sater AK, Ji H, Otchere AA, Daniel JM, McCrea PD. 2004. Non-canonical Wnt signals are modulated by the Kaiso transcriptional repressor and p120-catenin. Nat Cell Biol 6: 1212-1220.

Kioussi C, Briata P, Baek SH, Rose DW, Hamblet NS, Herman T, Ohgi KA, Lin C, Gleiberman A, Wang J, et al. 2002. Identification of a Wnt $/ \mathrm{Dvl} / \beta$-Catenin $->$ Pitx2 pathway mediating cell-type-specific proliferation during development. Cell 111: 673-685.

Klaus A, Saga Y, Taketo MM, Tzahor E, Birchmeier W. 2007. Distinct roles of $\mathrm{Wnt} / \beta$-catenin and Bmp signaling during early cardiogenesis. Proc Natl Acad Sci 104: 18531-18536.

Kobielak A, Fuchs E. 2006. Links between $\alpha$-catenin, NF-kappaB, and squamous cell carcinoma in skin. Proc Natl Acad Sci 103: 2322-2327.

Kobielak A, Pasolli HA, Fuchs E. 2004. Mammalian formin-1 participates in adherens junctions and polymerization of linear actin cables. Nat Cell Biol 6: 21-30.

Kostetskii I, Moore R, Kemler R, Radice GL. 2001. Differential adhesion leads to segregation and exclusion of N-cadherin-deficient cells in chimeric embryos. Dev Biol 234: 72-79.

Kwon C, Arnold J, Hsiao EC, Taketo MM, Conklin BR, Srivastava D. 2007. Canonical Wnt signaling is a positive regulator of mammalian cardiac progenitors. Proc Natl Acad Sci 104: 10894-10899.

Lampugnani MG, Orsenigo F, Gagliani MC, Tacchetti C, Dejana E. 2006. Vascular endothelial cadherin controls 
VEGFR-2 internalization and signaling from intracellular compartments. J Cell Biol 174: 593-604.

Larue L, Ohsugi M, Hirchenhain J, Kemler R. 1994 E-cadherin null mutant embryos fail to form a trophectoderm epithelium. Proc Natl Acad Sci 91: 8263-8267.

Lee DM, Kiener HP, Agarwal SK, Noss EH, Watts GF, Chisaka O, Takeichi M, Brenner MB. 2007. Cadherin-11 in synovial lining formation and pathology in arthritis. Science 315: 1006-1010.

Lele Z, Folchert A, Concha M, Rauch GJ, Geisler R, Rosa F, Wilson SW, Hammerschmidt M, Bally-Cuif L. 2002. parachute/n-cadherin is required for morphogenesis and maintained integrity of the zebrafish neural tube. Development 129: 3281-3294.

Lickert H, Kutsch S, Kanzler B, Tamai Y, Taketo MM, Kemler R. 2002. Formation of multiple hearts in mice following deletion of $\beta$-catenin in the embryonic endoderm. Dev Cell 3: 171-181.

Liebner S, Cattelino A, Gallini R, Rudini N, Iurlaro M, Piccolo S, Dejana E. 2004. $\beta$-catenin is required for endothelial-mesenchymal transformation during heart cushion development in the mouse. J Cell Biol 166: 359-367.

Lien WH, Klezovitch O, Vasioukhin V. 2006a. Cadherincatenin proteins in vertebrate development. Curr Opin Cell Biol 18: 499-506.

Lien WH, Klezovitch O, Fernandez TE, Delrow J, Vasioukhin V. 2006b. $\alpha$ E-catenin controls cerebral cortical size by regulating the hedgehog signaling pathway. Science 311: 1609-1612.

Lien WH, Klezovitch O, Null M, Vasioukhin V. 2008. $\alpha$ E-catenin is not a significant regulator of $\beta$-catenin signaling in the developing mammalian brain. J Cell Sci 121: $1357-1362$.

Lin L, Cui L, Zhou W, Dufort D, Zhang X, Cai CL, Bu L, Yang L, Martin J, Kemler R, et al. 2007. $\beta$-catenin directly regulates Islet1 expression in cardiovascular progenitors and is required for multiple aspects of cardiogenesis. Proc Natl Acad Sci 104: 9313-9318.

Luo Y, Radice GL. 2005. N-cadherin acts upstream of VE-cadherin in controlling vascular morphogenesis. J Cell Biol 169: 29-34.

Luo Y, Ferreira-Cornwell M, Baldwin H, Kostetskii I, Lenox J, Lieberman M, Radice G. 2001. Rescuing the $\mathrm{N}$-cadherin knockout by cardiac-specific expression of N- or E-cadherin. Development 128: 459-469.

Luo Y, High FA, Epstein JA, Radice GL. 2006. N-cadherin is required for neural crest remodeling of the cardiac outflow tract. Dev Biol 299: 517-528.

Machon O, van den Bout CJ, Backman M, Kemler R, Krauss S. 2003. Role of $\beta$-catenin in the developing cortical and hippocampal neuroepithelium. Neuroscience 122: 129-143.

Mah SP, Saueressig H, Goulding M, Kintner C, Dressler GR. 2000. Kidney development in cadherin-6 mutants: Delayed mesenchyme-to-epithelial conversion and loss of nephrons. Dev Biol 223: 38-53.

Malanchi I, Peinado H, Kassen D, Hussenet T, Metzger D, Chambon P, Huber M, Hohl D, Cano A, Birchmeier W, et al. 2008. Cutaneous cancer stem cell maintenance is dependent on $\beta$-catenin signalling. Nature 452: 650-653.

Manabe T, Togashi H, Uchida N, Suzuki SC, Hayakawa Y, Yamamoto $M$, Yoda $\mathrm{H}$, Miyakawa $T$, Takeichi $\mathrm{M}$, Chisaka O. 2000. Loss of cadherin-11 adhesion receptor enhances plastic changes in hippocampal synapses and modifies behavioral responses. Mol Cell Neurosci 15: 534-546.

Marose TD, Merkel CE, McMahon AP, Carroll TJ. 2008. $\beta$-catenin is necessary to keep cells of ureteric bud/ Wolffian duct epithelium in a precursor state. Dev Biol 314: $112-126$.

McMahon AP, Bradley A. 1990. The Wnt-1 (int-1) protooncogene is required for development of a large region of the mouse brain. Cell 62: 1073-1085.

McNeill H. 2009. Planar cell polarity: Keeping hairs straight is not so simple. Cold Spring Harb Perspect Biol 2: a003376.

Meng W, Takeichi M. 2009. Adherens junction: Molecular architecture and regulation. Cold Spring Harb Perspect Biol 1: a002899.

Mucenski ML, Wert SE, Nation JM, Loudy DE, Huelsken J, Birchmeier W, Morrisey EE, Whitsett JA. 2003. $\beta$-Catenin is required for specification of proximal/ distal cell fate during lung morphogenesis. $J$ Biol Chem 278: 40231-40238.

Nagafuchi A, Takeichi M, Tsukita S. 1991. The $102 \mathrm{kd}$ cadherin-associated protein: Similarity to vinculin and posttranscriptional regulation of expression. Cell 65: 849-857.

Nakagawa S, Takeichi M. 1998. Neural crest emigration from the neural tube depends on regulated cadherin expression. Development 125: 2963-2971.

Nemade RV, Bierie B, Nozawa M, Bry C, Smith GH, Vasioukhin V, Fuchs E, Hennighausen L. 2004. Biogenesis and function of mouse mammary epithelium depends on the presence of functional $\alpha$-catenin. Mech Dev 121: 91-99.

Niessen CM. 2007. Tight junctions/adherens junctions: Basic structure and function. J Invest Dermatol 127: 2525-2532.

Noben-Trauth K, Zheng QY, Johnson KR. 2003. Association of cadherin 23 with polygenic inheritance and genetic modification of sensorineural hearing loss. Nat Genet 35: $21-23$

Ogata S, Morokuma J, Hayata T, Kolle G, Niehrs C, Ueno N, Cho KW. 2007. TGF- $\beta$ signaling-mediated morphogenesis: Modulation of cell adhesion via cadherin endocytosis. Genes Dev 21: 1817-1831.

Ohnishi K, Melchers F, Shimizu T. 2005. Lymphocyteexpressed BILL-cadherin/cadherin-17 contributes to the development of B cells at two stages. Eur J Immunol 35: 957-963.

Ohsugi M, Hwang SY, Butz S, Knowles BB, Solter D, Kemler R. 1996. Expression and cell membrane localization of catenins during mouse preimplantation development. Dev Dyn 206: 391-402.

Ohsugi M, Larue L, Schwarz H, Kemler R. 1997. Cell-junctional and cytoskeletal organization in mouse blastocysts lacking E-cadherin. Dev Biol 185: 261-271.

Onder TT, Gupta PB, Mani SA, Yang J, Lander ES, Weinberg RA. 2008. Loss of E-cadherin promotes metastasis via 
multiple downstream transcriptional pathways. Cancer Res 68: 3645-3654.

Ong LL, Kim N, Mima T, Cohen-Gould L, Mikawa T. 1998. Trabecular myocytes of the embryonic heart require N-cadherin for migratory unit identity. Dev Biol 193: $1-9$.

Park C, Falls W, Finger JH, Longo-Guess CM, Ackerman SL. 2002a. Deletion in Catna2, encoding a N-catenin, causes cerebellar and hippocampal lamination defects and impaired startle modulation. Nat Genet 31: 279-284.

Park C, Finger JH, Cooper JA, Ackerman SL. 2002b. The cerebellar deficient folia (cdf) gene acts intrinsically in Purkinje cell migrations. Genesis 32: 32-41.

Park JS, Valerius MT, McMahon AP. 2007. Wnt/ $\beta$-catenin signaling regulates nephron induction during mouse kidney development. Development 134: 2533-2539.

Paulson AF, Fang X, Ji H, Reynolds AB, McCrea PD. 1999. Misexpression of the catenin p120(ctn) $1 \mathrm{~A}$ perturbs Xenopus gastrulation but does not elicit Wnt-directed axis specification. Dev Biol 207: 350-363.

Pece S, Gutkind JS. 2000. Signaling from E-cadherins to the MAPK pathway by the recruitment and activation of epidermal growth factor receptors upon cell-cell contact formation. J Biol Chem 275: 41227-41233.

Perez-Moreno M, Davis MA, Wong E, Pasolli HA, Reynolds AB, Fuchs E. 2006. p120-catenin mediates inflammatory responses in the skin. Cell 124: 631-644.

Perez-Moreno M, Song W, Pasolli HA, Williams SE, Fuchs E. 2008. Loss of p120 catenin and links to mitotic alterations, inflammation, and skin cancer. Proc Natl Acad Sci 105: 15399-15404.

Perrais M, Chen X, Perez-Moreno M, Gumbiner BM. 2007. E-Cadherin Homophilic Ligation Inhibits Cell Growth and Epidermal Growth Factor Receptor Signaling Independently of Other Cell Interactions. Mol Biol Cell 18: 2013-2025.

Piedra J, Miravet S, Castano J, Palmer HG, Heisterkamp N, Garcia de Herreros A, Dunach M. 2003. p120 Catenin-associated Fer and Fyn tyrosine kinases regulate $\beta$-catenin Tyr-142 phosphorylation and $\beta$-catenin- $\alpha$ catenin Interaction. Mol Cell Biol 23: 2287-2297.

Qian X, Karpova T, Sheppard AM, McNally J, Lowy DR. 2004. E-cadherin-mediated adhesion inhibits liganddependent activation of diverse receptor tyrosine kinases. Embo J 23: 1739-1748.

Radice GL, Ferreira-Cornwell MC, Robinson SD, Rayburn H, Chodosh LA, Takeichi M, Hynes RO. 1997a. Precocious mammary gland development in P-cadherin-deficient mice. J Cell Biol 139: 1025-1032.

Radice GL, Rayburn H, Matsunami H, Knudsen KA, Takeichi M, Hynes RO. 1997b. Developmental defects in mouse embryos lacking N-cadherin. Dev Biol 181: 64-78.

Reynolds AB. 2007. p120-catenin: Past and present. Biochim Biophys Acta 1773: 2-7.

Reynolds AB, Carnahan RH. 2004. Regulation of cadherin stability and turnover by p120ctn: Implications in disease and cancer. Semin Cell Dev Biol 15: 657-663.

Rhee J, Buchan T, Zukerberg L, Lilien J, Balsamo J. 2007. Cables links Robo-bound Abl kinase to
$\mathrm{N}$-cadherin-bound $\beta$-catenin to mediate Slit-induced modulation of adhesion and transcription. Nat Cell Biol 9: 883-892.

Riethmacher D, Brinkmann V, Birchmeier C. 1995. A targeted mutation in the mouse E-cadherin gene results in defective preimplantation development. Proc Natl Acad Sci 92: 855-859.

Rudini N, Felici A, Giampietro C, Lampugnani M, Corada M, Swirsding K, Garre M, Liebner S, Letarte M, ten Dijke P, et al. 2008. VE-cadherin is a critical endothelial regulator of TGF- $\beta$ signalling. Embo J 27: 993-1004.

Ruiz P, Brinkmann V, Ledermann B, Behrend M, Grund C, Thalhammer C, Vogel F, Birchmeier C, Gunthert U, Franke WW, et al. 1996. Targeted mutation of plakoglobin in mice reveals essential functions of desmosomes in the embryonic heart. J Cell Biol 135: 215-225.

Sehgal RN, Gumbiner BM, Reichardt LF. 1997. Antagonism of cell adhesion by an $\alpha$-catenin mutant, and of the Wnt-signaling pathway by $\alpha$-catenin in Xenopus embryos. J Cell Biol 139: 1033-1046.

Sheikh F, Chen Y, Liang X, Hirschy A, Stenbit AE, Gu Y, Dalton ND, Yajima T, Lu Y, Knowlton KU, et al. 2006. $\alpha$-E-catenin inactivation disrupts the cardiomyocyte adherens junction, resulting in cardiomyopathy and susceptibility to wall rupture. Circulation 114: 1046-1055.

Shoval I, Ludwig A, Kalcheim C. 2007. Antagonistic roles of full-length N-cadherin and its soluble BMP cleavage product in neural crest delamination. Development 134: 491-501.

Simcha I, Shtutman M, Salomon D, Zhurinsky J, Sadot E, Geiger B, Ben-Ze'ev A. 1998. Differential nuclear translocation and transactivation potential of $\beta$-catenin and plakoglobin. J Cell Biol 141: 1433-1448.

Soshnikova N, Zechner D, Huelsken J, Mishina Y, Behringer RR, Taketo MM, Crenshaw EB3rd, Birchmeier W. 2003. Genetic interaction between Wnt/ $\beta$-catenin and BMP receptor signaling during formation of the AER and the dorsal-ventral axis in the limb. Genes Dev 17: 1963-1968.

Suyama K, Shapiro I, Guttman M, Hazan RB. 2002. A signaling pathway leading to metastasis is controlled by $\mathrm{N}$-cadherin and the FGF receptor. Cancer Cell 2: 301-314.

Suzuki SC, Furue H, Koga K, Jiang N, Nohmi M, Shimazaki Y, Katoh-Fukui Y, Yokoyama M, Yoshimura M, Takeichi M. 2007. Cadherin-8 is required for the first relay synapses to receive functional inputs from primary sensory afferents for cold sensation. J Neurosci 27: 3466-3476.

Taddei A, Giampietro C, Conti A, Orsenigo F, Breviario F, Pirazzoli V, Potente M, Daly C, Dimmeler S, Dejana E. 2008. Endothelial adherens junctions control tight junctions by VE-cadherin-mediated upregulation of claudin-5. Nat Cell Biol 10: 923-934.

Takahashi K, Suzuki K. 1996. Density-dependent inhibition of growth involves prevention of EGF receptor activation by E-cadherin-mediated cell-cell adhesion. Exp Cell Res 226: $214-222$.

Tao Q, Yokota C, Puck H, Kofron M, Birsoy B, Yan D, Asashima M, Wylie CC, Lin X, Heasman J. 2005. Maternal wnt11 activates the canonical wnt signaling pathway required for axis formation in Xenopus embryos. Cell 120: 857-871. 


\section{Adhesive and Signaling Functions of Cadherins and Catenins}

Tinkle CL, Lechler T, Pasolli HA, Fuchs E. 2004. Conditional targeting of E-cadherin in skin: Insights into hyperproliferative and degenerative responses. Proc Natl Acad Sci 101: $552-557$.

Tinkle CL, Pasoli HA, Stokes N, Fuchs E. 2008. New insights into cadherin function in epidermal sheet formation and maintenance of tissue integrity. Proc Natl Acad Sci 105: 15405-15410.

Torres M, Stoykova A, Huber O, Chowdhury K, Bonaldo P, Mansouri A, Butz S, Kemler R, Gruss P. 1997. An $\alpha$-E-catenin gene trap mutation defines its function in preimplantation development. Proc Natl Acad Sci 94: 901-906.

Tunggal JA, Helfrich I, Schmitz A, Schwarz H, Gunzel D, Fromm M, Kemler R, Krieg T, Niessen CM. 2005. E-cadherin is essential for in vivo epidermal barrier function by regulating tight junctions. Embo $J$ 24: 1146-1156.

Uemura M, Takeichi M. 2006. $\alpha$ N-catenin deficiency causes defects in axon migration and nuclear organization in restricted regions of the mouse brain. Dev Dyn 235: 2559-2566.

van Buul JD, Anthony EC, Fernandez-Borja M, Burridge K, Hordijk PL. 2005. Proline-rich tyrosine kinase 2 (Pyk2) mediates vascular endothelial-cadherin-based cell-cell adhesion by regulating $\beta$-catenin tyrosine phosphorylation. J Biol Chem 280: 21129-21136.

Vasioukhin V, Bauer C, Yin M, Fuchs E. 2000. Directed actin polymerization is the driving force for epithelial cell-cell adhesion. Cell 100: 209-219.

Vasioukhin V, Bauer C, Degenstein L, Wise B, Fuchs E. 2001. Hyperproliferation and defects in epithelial polarity upon conditional ablation of $\alpha$-catenin in skin. Cell 104: $605-617$.

Wilson SM, Householder DB, Coppola V, Tessarollo L, Fritzsch B, Lee EC, Goss D, Carlson GA, Copeland NG,
Jenkins NA. 2001. Mutations in Cdh23 cause nonsyndromic hearing loss in waltzer mice. Genomics 74 : $228-233$.

Yamada S, Pokutta S, Drees F, Weis WI, Nelson WJ. 2005. Deconstructing the cadherin-catenin-actin complex. Cell 123: 889-901.

Yang X, Chrisman H, Weijer CJ. 2008. PDGF signalling controls the migration of mesoderm cells during chick gastrulation by regulating $\mathrm{N}$-cadherin expression. Development 135: 3521-3530.

Yin Y, White AC, Huh SH, Hilton MJ, Kanazawa H, Long F, Ornitz DM. 2008. An FGF-WNT gene regulatory network controls lung mesenchyme development. Dev Biol 319: 426-436.

Young P, Boussadia O, Halfter H, Grose R, Berger P, Leone DP, Robenek H, Charnay P, Kemler R, Suter U. 2003. E-cadherin controls adherens junctions in the epidermis and the renewal of hair follicles. Embo J 22: 5723-5733.

Zamora M, Manner J, Ruiz-Lozano P. 2007. Epicardiumderived progenitor cells require $\beta$-catenin for coronary artery formation. Proc Natl Acad Sci 104: 18109-18114.

Zechner D, Fujita Y, Hulsken J, Muller T, Walther I, Taketo MM, Crenshaw EB3rd, Birchmeier W, Birchmeier C. 2003. $\beta$-Catenin signals regulate cell growth and the balance between progenitor cell expansion and differentiation in the nervous system. Dev Biol 258: 406-418.

Zinser GM, Leonis MA, Toney K, Pathrose P, Thobe M, Kader SA, Peace BE, Beauman SR, Collins MH, Waltz SE. 2006. Mammary-specific Ron receptor overexpression induces highly metastatic mammary tumors associated with $\beta$-catenin activation. Cancer Res 66: 11967-11974.

Zohn IE, Li Y, Skolnik EY, Anderson KV, Han J, Niswander L. 2006. p38 and a p38-interacting protein are critical for downregulation of E-cadherin during mouse gastrulation. Cell 125: 957-969. 


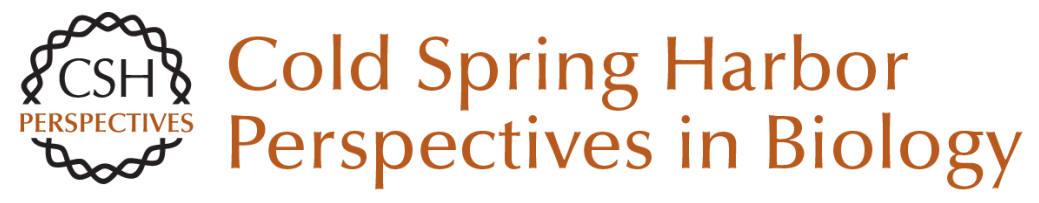

\title{
Adhesive and Signaling Functions of Cadherins and Catenins in Vertebrate Development
}

\author{
Ewa Stepniak, Glenn L. Radice and Valeri Vasioukhin
}

Cold Spring Harb Perspect Biol 2009; doi: 10.1101/cshperspect.a002949 originally published online August 26, 2009

\section{Subject Collection Cell-Cell Junctions}

Vascular Endothelial (VE)-Cadherin, Endothelial

Adherens Junctions, and Vascular Disease Maria Grazia Lampugnani, Elisabetta Dejana and Costanza Giampietro

Adherens Junctions and Desmosomes

Coordinate Mechanics and Signaling to

Orchestrate Tissue Morphogenesis and Function:

An Evolutionary Perspective

Matthias Rübsam, Joshua A. Broussard, Sara A. Wickström, et al.

Cell-Cell Contact and Receptor Tyrosine Kinase

Signaling

Christine Chiasson-MacKenzie and Andrea I. McClatchey

Hold Me, but Not Too Tight--Endothelial Cell-Cell Junctions in Angiogenesis

Anna Szymborska and Holger Gerhardt

Connexins and Disease

Mario Delmar, Dale W. Laird, Christian C. Naus, et al.

Cell Junctions in Hippo Signaling Ruchan Karaman and Georg Halder
Signaling by Small GTPases at Cell-Cell Junctions: Protein Interactions Building Control and Networks Vania Braga

Making Connections: Guidance Cues and

Receptors at Nonneural Cell-Cell Junctions lan V. Beamish, Lindsay Hinck and Timothy E. Kennedy

The Cadherin Superfamily in Neural Circuit Assembly James $D$. Jontes

Mechanosensing and Mechanotransduction at Cell-Cell Junctions Alpha S. Yap, Kinga Duszyc and Virgile Viasnoff

Beyond Cell-Cell Adhesion: Sensational

Cadherins for Hearing and Balance Avinash Jaiganesh, Yoshie Narui, Raul Araya-Secchi, et al.

Cell-Cell Junctions Organize Structural and Signaling Networks Miguel A. Garcia, W. James Nelson and Natalie Chavez

For additional articles in this collection, see http://cshperspectives.cshlp.org/cgi/collection/

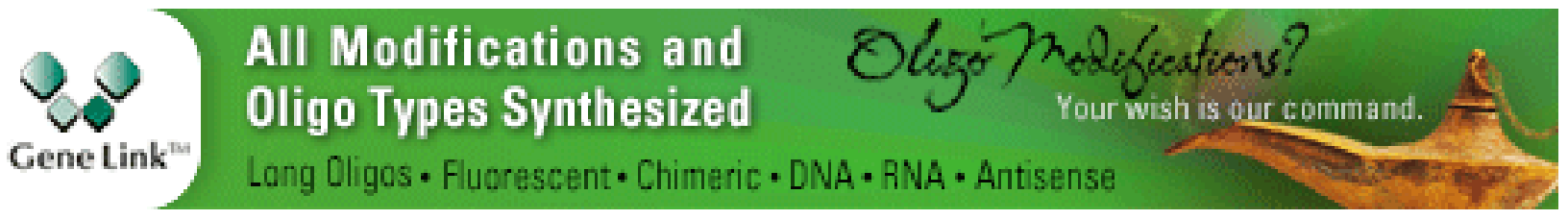


Loss of E-Cadherin-Dependent Cell-Cell Adhesion and the Development and Progression of Cancer Heather C. Bruner and Patrick W.B. Derksen

Desmosomes and Intermediate Filaments: Their Consequences for Tissue Mechanics

Mechthild Hatzfeld, René Keil and Thomas M. Magin
Cell Biology of Tight Junction Barrier Regulation and Mucosal Disease

Aaron Buckley and Jerrold R. Turner

Integration of Cadherin Adhesion and

Cytoskeleton at Adherens Junctions

René Marc Mège and Noboru Ishiyama

For additional articles in this collection, see http://cshperspectives.cshlp.org/cgi/collection/

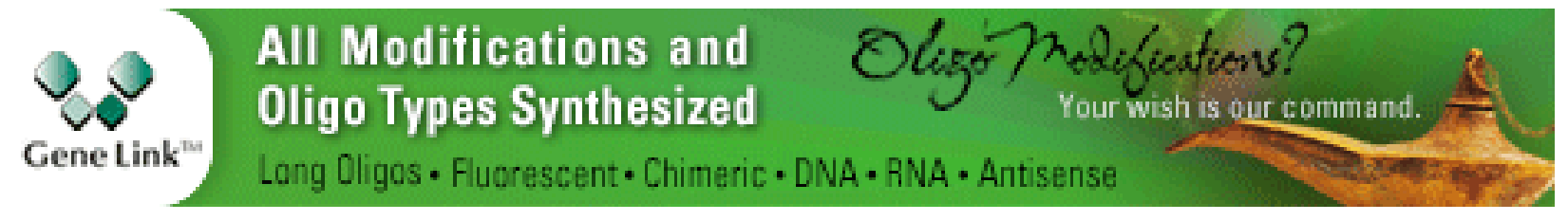

Copyright @ 2009 Cold Spring Harbor Laboratory Press; all rights reserved 